http://kitaibelia.unideb.hu/

ISSN 2064-4507 (Online) • ISSN 1219-9672 (Print)

(C) 2016, Department of Botany, University of Debrecen, Hungary

21 (2): 227-252.; 2016

DOI: $10.17542 /$ kit.21.227

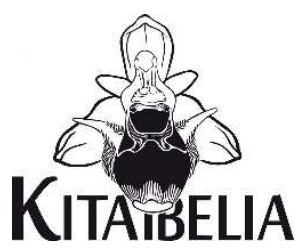

\title{
Pótlások Magyarország edényes növényfajainak elterjedési atlaszához II.
}

\author{
MolnÁr Csaba1 ${ }^{1}$, LENGyel Attila², MolnÁr V. Attilaª ${ }^{3}$ NAGY Timea ${ }^{4}$, CsÁBI Miklós ${ }^{5}$, \\ SÜVEgES Kristóf ${ }^{3}$, LENGYEL-VASKOR Dóra ${ }^{6}$, TóTH György ${ }^{7}$ \& TAKÁCS Attila ${ }^{3}$
}

(1) H-3728 Gömörszőlős, Kassai u. 34.

(2) MTA ÖK Ökológiai és Botanikai Intézet, H-2163 Vácrátót, Alkotmány u. 2-4.

(3) Debreceni Egyetem TTK Növénytani Tanszék, H-4032 Debrecen, Egyetem tér 1.

(4) Pannon Egyetem GK Növénytudományi és Biotechnológiai Tanszék, H-8360 Keszthely, Festetics u. 7.

(5) H-1035 Budapest, Kerék u. 4.

(6) H-2112 Veresegyház, Bölcsőde u. 3/1.

(7) H-2100 Gödöllő, Bessenyei György u. 3.

\section{Contributions to the Atlas Florae Hungariae II.}

\begin{abstract}
The present article is the second part of the series aiming to contribute with new data to the distribution maps published recently in Atlas Florae Hungariae. Current occurrence data of 612 vascular plant taxa from 283 flora mapping quadrates (CEU) are presented. New records are distributed over the entire Hungary, however, most are localised in the North Hungarian Mts. Occurrence data of rare native taxa (e.g. Antennaria dioica, Bupleurum pachnospermum, Carex rostrata, Ceratocephala testiculata, Cicuta virosa, Cirsium boujartii, Epipactis moravica, Lycopsis arvensis, Parnassia palustris, Pyrus nivalis, Rumex kerneri, Rumex pulcher, Silene nemoralis, Stellaria alsine, Teucrium botrys, Vicia lutea), rare or data-deficient alien taxa (e.g. Nonea lutea, Panicum dichotomiflorum, Silybum marianum) as well as frequent but more or less underrepresented taxa (e.g. Eragrostis minor, Heliotropium europaeum, Saxifraga tridactylites) are also enumerated, since our intention was to fill the gaps in the Atlas. Remarcable contribution on the occupied territory of Ranunculus illyricus and Spergula pentandra in the Nyírség region (E Hungary), and on the Hungarian distribution of expanding alien weed Senecio vernalis are also presented.
\end{abstract}

Keywords: distribution data, flora mapping, flora of Hungary, vascular flora

Összefoglalás - Jelen közleményünk annak a sorozatnak a második része, melynek célja a Magyarország edényes növényfajainak elterjedési atlasza térképeinek kiegészítése, fóként aktuális előfordulási adatokkal. Ezúttal 612 edényes taxon előfordulási adatait közöljük az ország szinte egész területéről (mintegy 283 flóratérképezési kvadrátból), de legnagyobb számban az Északiközéphegységből. Az adatok között ritkább őshonos taxonok (e.g. Antennaria dioica, Bupleurum pachnospermum, Carex rostrata, Ceratocephala testiculata, Cicuta virosa, Cirsium boujartii, Epipactis moravica, Lycopsis arvensis, Parnassia palustris, Pyrus nivalis, Rumex kerneri, Rumex pulcher, Silene nemoralis, Stellaria alsine, Teucrium botrys, Vicia lutea), ritka, vagy legalábbis adathiányos idegenhonos fajok (például Nonea lutea, Panicum dichotomiflorum, Silybum marianum) mellett országosan elterjedt, de többé-kevésbé alulreprezentált fajok (például Eragrostis minor, Heliotropium europaeum, Saxifraga tridactylites) esetében is közöljük az Atlasz térképeihez képest újnak bizonyuló lelőhelyeket. Közleményünk számottevően hozzájárul a Ranunculus illyricus és a Spergula pentandra nyírségi, valamint a Senecio vernalis hazai elterjedésének ismeretéhez.

Kulcsszavak: edényes flóra, elterjedési adatok, flóratérképezés, Magyarország flórája 


\section{Bevezetés}

Közleményünk a Magyarország edényes növényfajainak elterjedési atlasza (BARTHA et al. 2015) térképeinek kiegészítésére hivatott sorozat (TAKÁcs et al. 2016) második része. Ezúttal összesen 612 edényes taxon aktuális előfordulási adatait közöljük 283 flóratérképezési kvadrátból, amelyek elsősorban az Északi-középhegység területét reprezentálják (1. ábra). Az adatok szórvány jellegét jelzi, hogy 113 kvadrátból csupán egy-egy adatot közlünk, míg 100-nál többet csak egyetlen esetben (8381.2, Veresegyház-Őrbottyán). Utóbbi felhívja a figyelmet arra is, hogy egyes kvadrátok flóralistája mennyire hiányos.

Kilenc esetben gyűjtőfaj (agg.) szinten azonosítottuk a taxonokat, de amikor lehetséges volt a biztos határozás, az Atlaszban összevont térképen megjelenített alfajokat (például Vicia pannonica Crantz subsp. striata (M. Bieb.) Nyman) és „kisfajokat” (például Veronica hederifolia L. s. str. és $V$. triloba (Opiz) Wiesb.) is megkülönböztettük. Az adatokat 2004 és 2016 között gyűjtöttük, de többségük a 2016-os évből származik. A lelőhelyeket követően a közép-európai flóratérképezés kvadrátjainak azonosítói (NIKLFELD 1971) mellet feltüntetjük az adatközlők értelemszerű monogramjait (vö. szerzők, illetve a Köszönetnyilvánításban felsorolt adatközlők). A taxonok sorszámozása KIRÁLY (2009) munkáját követi.

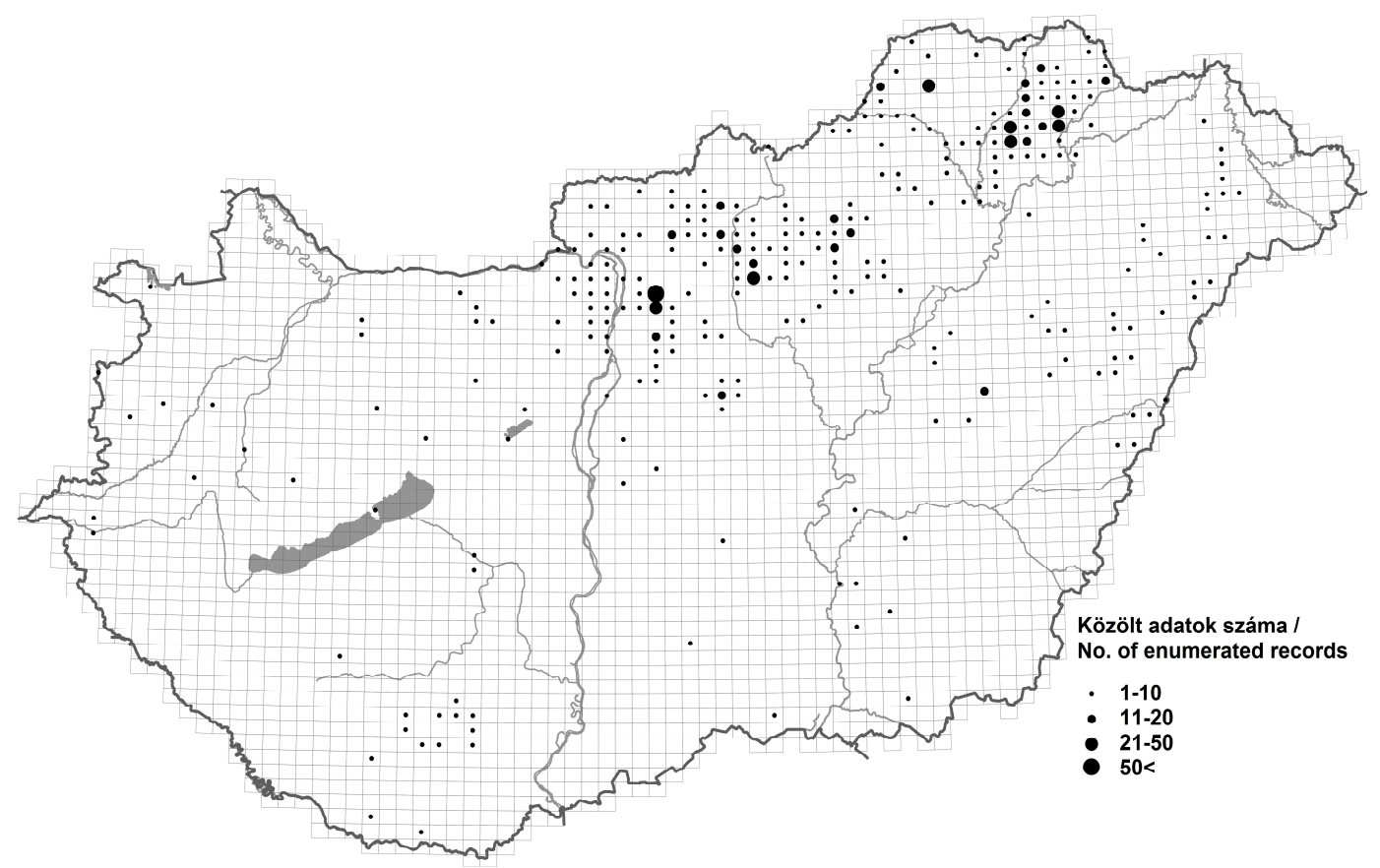

1. ábra. A közleményben összefoglalt előfordulási adatok a közép-európai flóratérképezés (KEF) hálórendszerének kvadrátjaira vetítve

Fig. 1. Distribution of localities of presented data, in projection of quadrates of the Central Europaean flora mapping system (CEU)

\section{Enumeráció}

8. Equisetum telmateia Ehrh. - Hidasnémeti-Hernádszurdok: Borsod-patak mente [7593.1, MCs]. 12.Equisetum fluviatile L. em. Ehrh. - Monok: Hosszú-völgy és Oláh-völgy [7792.4, MCs]; Tatárszentgyörgy: Szabadrét [8981.2, NT, TA, MVA]. 
17. Ophioglossum vulgatum L. - Fony: Nagy-Mocsáros, nedves kaszálón [7593.4, LA].

18. Botrychium Iunaria (L.) Sw. - Bükkszentkereszt: Lófő-tisztás, mezofil és sovány gyepekben [7989.4, LA]; Miskolc: Nagy-mező, mezofil és sovány gyepekben [7988.2, 7989.1, LA, KA]; Szilvásvárad: Zsidó-rét, mezofil és sovány gyepekben [7988.2, LA, KA].

26. Polypodium vulgare L. s. str. - Abaújszántó: Sulyom-hegy [7792.2, MCs]; Monok: Ingvár [7792.4, MCs]; Őrbottyán: Béke-telep, fekete- és erdeifenyő-ültetvényben [8381.2, LA, LVD].

28. Pteridium aquilinum (L.) Kuhn - Erdőbénye: Sajtház-völgy [7794.1, MCs]; Hernádpetri: Keserü-völgy feletti dombon [7493.3, MCs].

32.Asplenium scolopendrium L. - Alsópetény: Béke utca 16., kútban [8181.1, LA, LVD].

34. Asplenium javorkeanum Vida - Tatabánya: Szelim-barlang, mészkősziklafalon [8476.1, LA].

37. Asplenium trichomanes L. - Sárospatak: Király-hegy [7695.3, MCs].

39. Asplenium adiantum-nigrum L. - Budapest: Széll Kálmán tér, lakóház falán [8480.3, LA]. 40. Asplenium ruta-muraria L. - Sirok: Kis-Várhegy D-i oldala [8087.3, MCs].

43. Cystopteris fragilis (L.) Bernh. - Alacska: Cserebagos [7789.4, MCs].

46. Gymnocarpium dryopteris (L.) Newman - Erdőhorváti: Cseke-kő [7694.3, MCs]; Pilisszentkereszt: Dobogókő, erdei út rézsűjén [8279.3, LA].

47. Gymnocarpium robertianum (Hoffm.) Newman - Gyöngyössolymos: Kis-hegy, a Csák-kő sziklaüregében [8185.4, MCs].

56.Dryopteris carthusiana (Vill.) H.P.Fuchs - Erdőhorváti: Rózsás-völgy (Kavicsos-lápa) [7794.1, MCs]; Felsőtold: Hegymeg, Sándortanyától É-ra, Major-hegy lábánál [8083.2, MCs]; Mohora: a Berekalji-tótól északra, ültetett fenyvesben [7982.3, LA].

57. Dryopteris dilatata (Hoffm.) A.Gray - Fony: Fekete-patak menti égeresek [7693.2, MCs].

58. Dryopteris expansa (C. Presl) Fraser-Jenk. - Komlóska: a Zsidó-rét lápja mellett [7694.2, NT, TA].

61.Salvinia natans (L.) All. - Nagyhegyes: Keleti-főcsatorna [8493.4, SK].

98.Salix rosmarinifolia L. - Mogyoród: Álomhegyi-tó, lápréteken [8381.4, LA]; Vácrátót: Tece, lápréteken [8381.1, LA].

99.Salix purpurea L. - Veresegyház: Sződrákosi-patak mentén, bokorfüzesekben [8381.2, LA].

118. Carpinus betulus L. - Aldebrő: Cser [8187.3, MCs].

121. Corylus avellana L. - Nagyréde: Cseres [8284.2, MCs].

124. Castanea sativa Mill. - Bodrogkeresztúr: Csirke és Messzelátó [7894.1, MCs]; Tállya: Nyírjesek, néhány idős, ültetett fa és körötte számos fiatal és középkorú spontán újulat [7793.4, MCs].

125. Quercus cerris L. - Bodrogkisfalud: Vár-hegy. Nem őshonos, terjedőben. [7894.1, MCs].

131. Quercus pubescens agg. - Nagyréde: Cseres [8284.2, MCs].

137. Celtis occidentalis L. - Megyaszó: Kis-erdőtől délre [7892.3, MCs].

157. Asarum europaeum L. - Buják: Selyemrét [8083.3, MCs]; Szendrő: Billér-hegy [7690.1, MCs].

165. Persicaria dubia (Stein) Fourr. - Kemence-Királyháza: Kemence-patak völgye, üde erdei gyomnövényzetben [8079.2, LA].

178. Fallopia dumetorum (L.) Holub - Gyöngyössolymos: Kis-hegy [8185.4, MCs].

185. Rumex acetosella L. - Őrbottyán: bolygatott homoki gyepekben [8381.1, LA]; Veresegyház: bolygatott homoki gyepekben [8381.4, 8381.2, LA].

188. Rumex thyrsiflorus Fingerh. - Veresegyház: bolygatott gyepekben [8381.2, LA].

194. Rumex pulcher L. - Pécsvárad: vár, taposott gyomnövényzetben néhány-tíz tő [9876.1, LA]. 196. Rumex obtusifolius L. - Veresegyház: Fő út, útszéli gyomnövényzetben [8381.2, LA].

198. Rumex conglomeratus Murray - Gyöngyössolymos: a Csór-réti tározótól a Vörösmarty túristaház felé, vízvezeték nyomvonalán [8185.2, MCs].

204. Rumex kerneri Borbás - Szendrő-Szuhogy: Hideg-völgy, mocsárréten és az egykori mocsárrét becserjésedett szakaszain, annak szélén, hozzávetőlegesen 50 tő [7690.1, MCs]. 
210. Chenopodium aristatum L. - Veresegyház: Ligetek, útszéli gyomnövényzetben [8381.2, 8381.4, LA].

213. Chenopodium botrys L. - Dejtár: Lókos, útszélen [7981.3, LA]; Veresegyház: Ligetek, útszéli gyomnövényzetben [8381.2, LA].

217. Chenopodium glaucum L. - Dédestapolcsány: a Lázbérci-tározó mellett [7888.2, MCs]; Veresegyház: Malomköz, nedves gyomnövényzetben [8381.2, LA].

218. Chenopodium rubrum L. - Veresegyház: Ligetek, útszéli gyomnövényzetben [8381.2, LA].

221. Chenopodium polyspermum L. - Szegilong: Erdőbénye vasútállomás [7794.3, MCs]; Szendrő: Kis-hegy, tarlón [7690.1, MCs].

225. Chenopodium ficifolium Sm. - Bőcs: Nagy-Szög, belvizes szántón [7991.4, NT, TA]; Veresegyház: Álomvölgyi-víztározó, vízparti ruderális növényzetben [8381.4, LA].

226. Chenopodium opulifolium Schrad. - Tarnabod: temető [8387.1, SK].

232. Atriplex tatarica L. - Veresegyház: Ligetek, ruderális gyomnövényzetben [8381.2, LA].

236. Atriplex patula L. - Gömörszőlős: belterület, udvarokon [7688.2, MCs]; Sirok: Darnóhegy [8087.3, MCs]; Szegilong: Erdőbénye vasútállomás [7794.3, MCs]; Szendrő: Kis-hegy, erdei út mentén és földút szélén [7690.1, MCs].

238. Atriplex sagittata Borkh. - Szendrő: Kis-hegy, földút szélén [7690.1, MCs].

244. Kochia Ianiflora (S.G. Gmel.) Borbás - Veresegyház: Ligetek, bolygatott homoki gyepekben [8381.2, LA].

255. Salsola kali L. - Veresegyház: Ligetek, bolygatott homoki gyepekben, útszéleken [8381.2, LA].

262. Amaranthus powellii S.Watson - Putnok: vasútállomás [7788.2, MCs]; Veresegyház: ruderális élőhelyeken [8381.2, 8381.4, LA].

264. Amaranthus blitum L. - Budapest: Kelenföld, kertekben [8580.1, LA]; Hetes: belterületen, kertekben [9572.3, NT, TA]; Szombathely: Szelestey László utca, virágládákban gyom [8765.4, LA].

266. Amaranthus blitoides S. Watson - Jászberény: Sasközpont [8485.2, SK]; Veresegyház: ruderális élőhelyeken [8381.2, 8381.4, LA].

267. Amaranthus crispus (Lesp. et Thévenau) N. Terracc. - Nagyhegyes: belterületen [8494.3, SK]; Ozora: Égettházpuszta, baromfiudvarokban [9276.1, LA].

269. Amaranthus albus L. - Veresegyház: ruderális élőhelyeken [8381.2, 8381.4, LA].

272. Oxybaphus nyctagineus (Michx.) Sweet - Veresegyház: Ligetek, útszéli gyomnövényzetben [8381.2, LA].

278. Montia fontana L. subsp. chondrosperma (Fenzl) Walters - Hencida: Nagy-Cseres (Csere-erdő) [8796.3, MVA]; Sitke: Sitkei-erdő [8768.1, KL, MVA].

283. Moehringia trinervia (L.) Clairv. - Nagyréde: Cseres [8284.2, MCs].

293. Stellaria pallida (Dumort.) Piré - Veresegyház: száraz gyomnövényzetben [8381.2, LA].

296. Stellaria alsine Grimm - Gyöngyössolymos: a Csór-réti tározótól a Vörösmarty túristaház felé, vízvezeték nyomvonalán [8185.2, MCs].

297. Stellaria graminea L. - Hangony: temető [7787.3, MVA, SK].

300. Cerastium dubium (Bastard) Guépin - Pomáz: Dera-patak völgye, gyomos, felülvetett, nedves gyepben [8379.2, LA].

302. Cerastium tenoreanum Ser. - Bodrogkisfalud: Vár-hegy [7894.1, MCs].

305. Cerastium semidecandrum L. - Veresegyház: szárazgyepekben [8381.2, LA].

313. Moenchia mantica (L.) Bartl. - Vác: Gyadai-rétek, mezofil gyepben [8180.4, LA].

315. Sagina procumbens L. - Kazincbarcika: Egressy Béni út mentén, járdarepedésekben $[7789.2,7789.4, \mathrm{MCs}]$.

330. Spergula pentandra L. - Baktalórántháza-Flóratanya: temető [8098.2, MVA]; Érpatak: temető [8196.4, MVA]; Hencida: Nagy-Cseres (Csere-erdő) [8796.3, MVA]; Jármi: temető [8099.1, MVA]; Nagykálló: temető [8196.2, MVA]; Nyírbéltek: temető [8398.2, MVA]; 
Nyírlugos: temető [8398.1, MVA]; Nyírmártonfalva: temető [8497.1, MVA]; Őr: temető [8099.1, MVA]; Papos: temető [8099.1, MVA]; Vaja: temető [7999.3, MVA].

332. Spergularia rubra (L.) J.Presl et C.Presl - Bodony: Lágyasi-legelő [8085.4, MCs]; Erdőbénye: Tér-hegy [7794.1, MCs].

335. Lychnis coronaria (L.) Desr. - Bér: Filagória-hegy és Kis-Mulató-hegy [8182.2, MCs].

336. Lychnis viscaria L. - Megyaszó: Halom alja [7892.2, MCs].

337. Agrostemma githago L. - Pánd: Hársas-völgy, parlagon [8683.4, MCs].

339-340. Silene otites agg. - Kerecsend: Lógó-part [8288.1, MCs].

343. Silene conica L. - Veresegyház: Ligetek, nyílt, bolygatott homoki gyepekben [8381.2, LA].

346. Silene dichotoma Ehrh. - Rimóc: Hosszú-völgy és Bükkös-völgy közötti hegy [7983.3, MCs].

348. Silene bupleuroides L. - Hort: Cseplye [8284.4, MCs].

350. Silene viscosa (L.) Pers. - Mezőzombor: Fecskés, felhagyott faluszéli legelőn [7893.1, MCs].

351. Silene nemoralis Waldst. et Kit. - Gömörszőlős: Pozsok, felhagyott gyümölcsösben szórványosan néhány tő [7688.2, MCs].

352. Silene noctiflora L. - Domoszló: Pipis-hegy oldala, törmelékes bokorerdőben [8186.4, MCs].

353. Silene nutans L. - Monok: Ingvár, Zsebrik, Zsebrik és a falu között [7792.4, MCs].

360. Gypsophila paniculata L. - Tápióbicske: Agyagásó [8684.1, MCs].

364. Petrorhagia prolifera (L.) P.W.Ball et Heywood - Boldogkőúffalu: Kőtenger [7693.3, MCs]; Debrecen: Dóczy József u., Teniszke grill büfé [8495.2, SK].

376. Dianthus collinus Waldst. et Kit. - Erdőbénye: Becsk, Ördög-kő-sor, Dió-kút, Mondohaerős, Messzelátó alja, Mogyorósok, Palánkos [7794.1, MCs]; Felsőregmec: Nád-kút kis rétje és az Első-Forduló Pókháza felöl jövő patakjának keskeny rétje [7595.2, MCs]; Mátraballa: Senki rétje verő [8085.2, MCs]; Olaszliszka: Bundás-kereszt [7794.1, MCs]; Sátoraljaújhely: Szár-hegy, Vár-hegy és Fekete-hegy [7695.2, MCs]; Tarnaszentmária: Közös és attól K-re [8187.1, MCs]; Tornyosnémeti: Harasztka és Kecske-hegy mellett [7493.3, MCs].

384. Ceratophyllum submersum L. - Prügy: Úrrét, belvizes szántón [7893.3, NT, TA].

391. Nigella arvensis L. - Apc-Rózsaszentmárton-Szücsi: Tarcod [8184.3, MCs].

394. Isopyrum thalictroides L. - Szada: Margita [8381.4, MCs].

395. Actaea spicata L. - Nagylóc-Garáb: Nagy-Zsunyi-hegy [8083.2, MCs].

398. Aconitum anthora L. - Gödöllő: Gudra [8382.3, MCs].

404. Consolida orientalis (J.Gay) Schrödinger - Sámsonháza: Kis-Zagyva mentén [8084.1, MCs].

409. Anemone sylvestris L. - Boldogkőújfalu: Falu-hegy és Fekete-hegy [7693.4, MCs]; Nagytarcsa: Küdői-hegy [8481.4, MCs]; Tatabánya: Csúcsos-hegy lábainál, melegkedvelő tölgyes tisztásán [8476.1, LA].

414. Pulsatilla grandis Wender. - Tállya: Patócs-hegy [7793.3, MCs].

417. Pulsatilla zimmermannii Soó - Boldogkőúffalu: Falu-hegy és Fekete-hegy [7693.4, MCs];

Legyesbénye: Fuló-hegy [7892.2, MCs]; Sárospatak: Mandulás és Páncél-hegy [7695.3, MCs].

423. Clematis recta L. - Erdőbénye: Cigány-hegy, Nagy-Mondoha és Mondoha-erős [7794.1,

MCs]; Gyöngyössolymos: Tarma-oldal [8185.4, MCs].

424. Adonis vernalis $\mathrm{L}$. - Hort: Cseplye [8284.4, MCs].

436. Ranunculus pedatus Waldst. et Kit. - Balmazújváros: temető [8393.4, MVA]; Bekecs:

Nagy-hegy [7893.1, MCs]; Gödöllő: Alsópark, taposott gyomnövényzetben [8482.1, LA]; Legyesbénye: Majos [7892.2, MCs]; Pánd: Hársas-völgy [8683.4, MCs].

437. Ranunculus illyricus L. - Abaújszántó: Sulyom-hegy [7792.2, MCs]; Balkány: temető [8297.1, MVA]; Boldogkőújfalu: Falu-hegy és Fekete-hegy [7693.4, MCs]; Gemzse: Izraelita temető [7899.3, NT, TA]; Gemzse: temető [7899.3, NT, TA]; Ilk: ótemető [7899.3, NT, TA]; Jármi: temető [8099.1, MVA]; Kántorjánosi: temető [8098.4, MVA]; Kisvárda: Gyár utcai temető [7798.4, NT, TA]; Monok: Pipiske [7892.2, MVA]; Nyírderzs: temető [8098.4, MVA]; Nyírlugos: ótemető [8398.1, MVA]; Nyírmada: ótemető [7999.1, NT, TA]; Nyírvasvári: 
temető [8199.3, MVA]; Ópályi: ótemető [8099.2, NT, TA]; Papos: temető [8099.1, MVA]; Tiszaörs: temető [8490.4, MVA]; Tiszaszentimre: temető [8590.1, MVA].

439. Ranunculus lateriflorus DC. - Hencida: Nagy-Cseres (Csere-erdő) [8796.3, MVA].

440. Ranunculus polyphyllus Waldst. et Kit. - Hencida: Nagy-Cseres (Csere-erdő) [8796.3, MVA]; Hortobágy: Szálka-halom, árokban [8493.1, MVA].

448. Ranunculus arvensis L. - Pásztó: Bogaras [8183.2, MCs].

450. Ranunculus auricomus agg. - Feldebrő: Cser [8187.3, MCs].

454. Ranunculus lanuginosus L. - Gömörszőlős: Egerdő [7688.2, MCs].

457. Ceratocephala testiculata (Crantz) Roth - Verőce: Lőcs-oldal, meredek oldalban, a vadak miatt felszakadozó lejtősztyeppréten, kimondottan nyílt talajfelszínen 2007-ben néhány tucat tő virágzott, de az állománynagyság évről-évre jelentősen ingadozik. [8180.3, MCs].

462. Thalictrum minus L. - Monok: Hosszú-völgy és Oláh-völgy [7792.4, MCs].

466. Thalictrum lucidum L. - Sirok: Kígyós-patak völgye [8087.3, MCs].

470. Berberis vulgaris L. - Ecseg: Keresztvölgy-pusztától D-re lévő domb [8183.2, MCs]; Nagytarcsa: Küdői-hegy [8481.4, MCs]; Tápióság: Pándi-hegy [8683.2, MCs]; Veresegyház: Ligetek, száraz cserjésekben [8381.2, LA].

471. Mahonia aquifolium agg. - Pásztó: Muzslai üdülő felett [8184.1, MCs]; Veresegyház: Ligetek, akác- és fenyőültetvényekben [8381.2, LA]. Mindkét helyen kivadult állomány.

485. Corydalis cava L. - Aldebrő: Cser, leromlott állapotú gyertyános-kocsányos tölgyesben [8187.3, MCs].

488. Corydalis solida L. - Aldebrő: Cser [8187.3, MCs]; Golop: Golopi-erdő [7792.4, MCs]; Monok: Szőlős-hegy, Őr-hegy [7792.4, MCs]; Monok: Kővágótól Ny-ra [7792.4, MCs].

491. Fumaria officinalis L. - Szögliget: Szádvár [7489.4, MCs].

496. Sisymbrium strictissimum L. - Megyaszó: Hernád-magaspart, bozótosban [7792.3,

7892.1, MCs]; Szurdokpüspöki-Zagyvaszentjakab: Nagy-almás [8184.1, MCs].

505. Isatis tinctoria L. - Eger-Szarvaskő: Veres-oldal [8087.2, MCs].

506. Bunias orientalis L. - Tar: Dolinától D-re [8084.1, MCs].

516. Hesperis tristis - Abaújszántó: Sátor-hegy [7793.1, TA].

518. Hesperis sylvestris Crantz - Megyaszó: Hernád-magaspart, bozótosban [7792.3, 7892.1, MCs]. 527. Rapistrum perenne (L.) All. - Abaújszántó: Bűdi-járó, mezsgyén [7793.1, MCs]; Abaújszántó-Abaújkér: Gyür-tető és völgy [7793.1, MCs]; Bercel: Farkasberek-puszta [8182.2, MCs]; Nógrádsáp: Répás [8182.1, MCs].

538. Cardamine parviflora L. - Kismarja: Fertő-nádas [8796.4, MVA].

539. Cardamine hirsuta L. - Veresegyház: Miklóssy Kertészet, üde gyomnövényzetben [8381.2, LA].

547. Arabis glabra (L.) Bernh. - Legyesbénye: Fuló-hegy [7892.2, MCs]; Monok: Kővágó-tető alja [7792.4, MCs].

554. Lunaria annua L. - Gömörszőlős: belterület [7688.2, MCs].

556. Alyssum alyssoides L. - Őrbottyán: Alsó-rétek, bolygatott homoki gyepekben [8381.2, LA].

557. Alyssum desertorum Stapf - Fót: Somlyó, bolygatott homoki gyepekben [8381.3, LA]; Ő́rbottyán: Alsó-rétek, bolygatott homoki gyepekben [8381.1, LA]; Veresegyház: Ligetek, bolygatott homoki gyepekben [8381.2, LA].

558. Alyssum montanum L. - Abaújszántó: Sulyom-hegy [7792.2, MCs]; Abaújszántó-Pere: Süveges-hegy [7792.2, MCs].

559. Alyssum tortuosum Willd. - Pécel: Száraz-hegy [8582.1, MCs].

560. Berteroa incana (L.) DC. - Bánréve: határátkelő mellett [7688.3, MCs].

561. Aurinia saxatilis (L.) Desv. - Fony: Sólyom-kő [7593.4, MCs].

569. Draba nemorosa L. - Monok: Hosszú-völgy [7792.4, MCs].

574. Camelina microcarpa Andrz. ex DC. - Monok: Hosszú-völgy [7792.4, MCs]; Pécel: Száraz-hegy [8582.1, MCs]. 
583. Thlaspi perfoliatum L. - Pánd: Hársas-völgy [8683.4, MCs]; Veresegyház: nyílt gyepekben, gyomtársulásokban [8381.2, LA].

589. Thlaspi jankae A.Kern - Verpelét: a Cser-erdőtől É-ra lévő gyepekben [8187.3, MCs].

603. Coronopus squamatus (Forssk.) Asch. - Karcag: Csőreg-dűlő, földúton [8691.4, NT,

TA]; Szentes: Derzsi Kovács Jenő u. [9387.1, NT, TA].

622. Calepina irregularis (Asso) Thell. - Pocsaj: Kasza-puszta [8797.1, MVA]; Tihany: Kiserdő-tető, a Szélmarta sziklák alatt és Gödrös, a Diósi-rétek felett [9073.3, MCs].

625. Reseda luteola L. - Szendehely: Kapáskúti-patak völgyében, útszéli gyomnövényzetben [8180.2, LA, LVD].

633. Sempervivum marmoreum Griseb. - Arka-Boldogkőváralja: Tó-hegy [7693.1, MCs].

647. Saxifraga tridactylites L. - Eger-Szarvaskő: Veres-oldal [8087.2, MCs]; Putnok: vasútállomás [7788.2, MCs]; Tállya: Patócs-hegy [7793.3, MCs]; Tihany: Kiserdő-tető, a Szélmarta sziklák alatt és Gödrös, a Diósi-rétek felett [9073.3, MCs].

653. Parnassia palustris L. - Nagyvisnyó: Nagy-mező, töbrök alján gyakori [7988.2, LA, KA]. 654. Ribes uva-crispa L. - Pásztó: Omlás-völgy [8184.1, MCs].

656. Ribes aureum Pursh - Veresegyház: Ligetek, felhagyott kertekben, gyümölcsösökben terjed [8381.3, LA].

663. Spiraea media F. Schmidt - Putnok: Zsidóvár [7688.4, MCs].

670. Rubus idaeus L. - Apc: Kolin-völgy [8184.3, MCs]; Pálosvörösmart: Pipis-hegy Benevölgy felé néző lábánál [8185.4, MCs]; Sirok: a Dorgó feletti erdőkben és Liszkó, Palyaghegy [8087.3, MCs].

678. Rosa spinosissima L. - Hidasnémeti: Perényi-szőlők [7493.3, MCs].

709. Agrimonia procera Wallr. - Nógrádsipek: Köles-tarló [8083.1, MCs]; Rimóc: Hollókőipatak mente [8083.1, MCs].

711. Sanguisorba officinalis L. - Sirok: Nagy-Várhegy Ny-i lába [8087.3, MCs]; Tolcsva: Malom-hegy [7794.2, MCs].

719. Potentilla rupestris L. - Boldogkőújfalu: Falu-hegy és Fekete-hegy [7693.4, MCs];

Tállya: a Vár-hegytől ÉNy-ra lévő parlagokon, a Hollós-tető nyúlványán [7793.4, MCs].

720. Potentilla alba L. - Abaújszántó-Abaújkér: Gyűr-tető és völgy [7793.1, MCs]; Boldogkőváralja-Hernádcéce: Aba-hegy [7693.3, MCs]; Erdőbénye: Mondoha-erős [7794.1, MCs]; Erdőhorváti: Dóka- és Kavicsos-rét [7794.1, MCs].

723. Potentilla supina L. - Csécse: Alsó-rétek [8183.2, MCs]; Gömörszőlős: belterület, udvar betonjának repedésében [7688.2, MCs]; Gyöngyöshalász: a halastó mellett [8285.4, MCs]; Karcag: az Apavári-erdőtől Ny-ra, a 4-es út mentén, belvizes szántón [8691.4, NT, TA].

724. Potentilla erecta (L.) Rausch - Baskó: Bika-rét [7694.3, MCs].

731. Potentilla heptaphylla L. - Pécel: Hársas [8482.3, MCs]; Verpelét: a Cser-erdőtől É-ra lévő gyepekben [8187.3, MCs].

734. Potentilla arenaria Borkh. - Veresegyház: Ligetek, homoki gyepekben [8381.2, LA].

737. Fragaria moschata Duchesne - Pilisszántó: Szanatórium mellett, cseres-tölgyesben [8379.1, LA].

755. Pyrus nivalis Jacq. - Kisnána: Macskavár, igen régen felhagyott szőlőben, az egykori határoló kősáncokon néhány fácska [8186.4, MCs]; Komlóska: Temető felett, Podinka, egy fácska felhagyott gyümölcsös helyén lévő bozótban [7694.4, MCs]; Pilisborosjenő: NagyKevély, karsztbokorerdő tisztásán néhány példány [8379.4, LA].

761. Sorbus domestica L. - Erdőbénye: Peres, Palánkos, Dió-kút [7794.1, MCs]; Feldebrő: Cser [8187.3, MCs]; Felsőregmec: Mátyásháza [7595.2, MCs]; Nagyréde: Cseres [8284.2, MCs]; Olaszliszka: Rakottyás, Csontos [7794.1, MCs]; Sátoraljaújhely: Fekete-hegy lába [7695.2, MCs]; Tállya: a Vár-hegytől ÉNy-ra lévő parlagokon, a Hollós-tető nyúlványán [7793.4, MCs]; Tornyosnémeti: Harasztka [7493.3, MCs]; Vécs: Farkas-aszó-oldal [8187.3, MCs].

817. Padus avium Mill. - Veresegyház: Ligetek, spontán cserjésekben [8381.2, LA]. 
821. Cerasus fruticosa (Pall.) Woronow - Fony: Messzelátó és Nagy-Muhar [7593.4, MCs].

824. Amygdalus nana L. - Apc-Rózsaszentmárton: Tarcod [8184.3, MCs]; Ecséd: az M3-as Ecsédi pihenőhelye mellett [8284.4, MCs]; Feldebrő: Cser [8187.3, MCs]; Kisnána: Macskavár [8186.2, MCs]; Legyesbénye: Fuló-hegy [7892.2, MCs]; Rózsaszentmárton: Tarcodi-pincék [8184.3, MCs].

828. Prunus cerasifera Ehrh. - Veresegyház: Ligetek, spontán cserjésekben [8381.2, LA].

834. Laburnum anagyroides Medik. - Abaújszántó: a Sátor-hegy nyugati oldalán, feketefenyvesben, egy idős fa [7793.1, MCs].

838. Chamaecytisus supinus (L.) Link - Korlát: Kővágó [7693.1, MCs]; Legyesbénye: Fulóhegy DK-i oldala [7892.2, MCs]; Monok: Zsebrik alja, Borjú-völgy felé [7792.4, MCs].

839. Chamaecytisus virescens (Kováts ex Neilr.) Dostál - Bercel: Galga menti dombok [8182.1, MCs]; Nógrádsáp: Répás és Malom-dűlő [8182.1, MCs].

841. Chamaecytisus albus (Hacq.) Rothm. - Erdőbénye: Holhós-tető [7794.3, MCs]; Gömörszőlős: Pozsok, Pozsár, Zánkó-hegy, Temető-oldal [7688.2, MCs].

844. Chamaecytisus ratisbonensis (Schaeff.) Rothm. - Abaújszántó-Abaújkér: Gyűr-tető oldala [7793.1, MCs]; Bekecs: Nagy-hegy [7893.1, MCs]; Legyesbénye: Fuló-hegy [7892.2, MCs]; Mikóháza: Polyán alatt [7595.2, MCs]; Sárospatak-Végardó: Somlyód [7695.2, MCs].

848. Genista germanica L. - Erdőbénye: Meszes-tisztás [7794.3, MCs]; Kelemér: Nyolcadrész [7688.2, MCs].

851. Genista tinctoria L. - Hort: Cseplye [8284.4, MCs]; Szendrő: Billér-hegy [7690.1, MCs]. 860. Galega officinalis L. - Hernádcéce: Berek [7693.3, MCs]; Nógrádsipek: Kis-kőkapu alatt [8083.1, MCs].

861. Colutea arborescens L. - Csécse: Bélahalom-puszta [8183.2, MCs].

874. Astragalus onobrychis L. - Mátraballa: Balla-völgy [8085.2, MCs].

879. Amorpha fruticosa L. - Monok: Hosszú-völgy [7792.4, MCs].

888. Vicia tetrasperma (L.) Schreb. - Vác: Gyadai-rétek, erdőszéleken [8180.4, LA].

891. Vicia pisiformis L. - Korlát: Kővágó [7693.1, MCs]; Monok: Zsebrik Ny-i oldalában, felhagyott gyümölcsösben [7792.4, MCs].

897. Vicia tenuifolia Roth - Hort: Cseplye [8284.4, MCs].

900. Vicia lathyroides L. - Fülöp: temető [8398.3, MVA]; Hencida: temető [8796.3, MVA]; Zalaszegvár: temető [8869.3, MVA].

901.2. Vicia pannonica Crantz subsp. striata (M. Bieb.) Nyman - Derekegyház: Téglás [9487.4, NT, TA]; Kisújszállás: Nagyerdő [8790.3, MCs]; Legyesbénye: Lete-erdőtől D-re [7892.2, MCs]; Tarnabod: a községhatár K-i részén fekvő bányatavak körül [8387.2, NT, TA].

902. Vicia lutea L. - Magyarszék: Ligeti-irtás, gyomos legelőn [9775.3, LA].

903. Vicia grandiflora Scop. - Veresegyház: gyomtársulásokban [8381.2, LA].

908. Vicia angustifolia L. - Veresegyház: gyomtársulásokban [8381.2, LA].

911. Lathyrus nissolia L. - Pásztó: Muzslai üdülő felett [8184.1, MCs]; SzurdokpüspökiZagyvaszentjakab: Nagy-almás [8184.1, MCs]; Tarcal: Aszú-fa-hát, szikesedő kaszálórét magasabban fekvő részén [7893.4, MCs]; Vilyvitány: Vilyi-legelő [7595.1, MCs].

916. Lathyrus hirsutus L. - Bodrogkisfalud: Vár-hegy [7894.1, MCs]; Erdőbénye: Becsk [7794.1, MCs]; Kisnána: Úsztató mellett [8186.2, MCs]; Mátraszőlős: Sátor-hegy és Kerekbükk közötti tisztás [8084.1, MCs]; Sátoraljaújhely: Rettel-dűlő [7695.2, MCs]; Tállya: Dorgó alja és Vány-hegy, művelt szőlők között és azok szegélyén [7793.4, MCs].; Hidasnémeti: Perényi-szőlők [7493.3, MCs]; Kárász: Kopasz-hegy [9775.2, MCs]; Parád: Ilona-völgy menti rétek [8186.1, MCs].

926. Lathyrus lacteus (M. Bieb.) Wissjul. - Boldogkőújfalu: Falu-hegy és Fekete-hegy [7693.4, MCs]; Gyöngyössolymos: Tarma-oldal [8185.4, MCs]; Kerecsend: Lógó-part [8288.1, MCs]; Nyirád: Szőc felé, műút mentén (Pörös-Remecse) [8970.4, MVA].

929. Lathyrus vernus (L.) Bernh. - Szendrő: Billér-hegy [7690.1, MCs]. 
935. Ononis arvensis L. - Gyöngyöshalász: a falu alatti mocsárréteken [8285.4, MCs].

949. Medicago monspeliaca (L.) Trautv. - Fót: Somlyó, szárazgyepben [8381.3, LA]; Őrbottyán: téglagyár, rekultivált terület szárazgyepében [8381.2, LA]; Veresegyház: Pamuttó északi részén, bolygatott homokfelszínen [8381.4, LA].

953. Medicago minima (L.) L. - Nagykálló: temető [8196.2, LBA, LKÁ, MVA].

961. Trifolium aureum Pollich - Kisnána: Ördögvályú-völgy [8186.2, MCs]; Szegi: Cigánytető, vadfölddé alakított tisztáson [7794.3, MCs].

964. Trifolium strictum L. - Szentes: Hékéd [9387.2, NT, TA].

966. Trifolium angulatum Waldst. et Kit. - Mezőzombor: Fecskés, felhagyott faluszéli legelőn [7893.1, 7893.3, MCs].

967. Trifolium montanum L. - Buják: Henyelpuszta felett [8183.2, MCs]; Ecseg: Bogdány [8183.2, MCs].

968. Trifolium retusum L. - Gyöngyös: Sár-hegy, parlagon [8285.2, MCs].

970. Trifolium fragiferum L. - Mátraszőlős: Hosszú-völgy, műút szélén [8084.3, MCs]; Nógrádkövesd: Száraz-tó [8182.1, MCs]; Tiszalúc: Harmadik-vető útmezsgyéje és Felsőlúcpuszta [7992.1, MCs].

972. Trifolium rubens L. - Feldebrő: Cser [8187.3, MCs]; Gyöngyöspata-Gyöngyöstarján: Havas [8184.4, MCs]; Korlát: Kővágó [7693.1, MCs]; Rózsaszentmárton: Tarcodi pincék [8184.3, MCs]; Szendehely: Lósi-patak völgyében, száraz erdőszegélyeken [8180.2, LA].

973. Trifolium alpestre L. - Kisnána: Középső-hegy [8186.2, MCs]; Korlát: Kővágó [7693.1, MCs]. 975. Trifolium ochroleucon Huds. - Erdőbénye: Barna-máj [7794.1, MCs]; Feldebrő: Cser [8187.3, MCs]; Rimóc: Fekete-hegy lába, Mengyi-szállás felé [8083.2, MCs]; Visonta: Szurdok-tető [8285.2, MCs].

976. Trifolium pannonicum Jacq. - Boldogkőváralja-Hernádcéce: Aba-hegy [7693.3, MCs]; Orfü: a 6604 út és a K+ turistajelzés kereszteződésénél, mezofil réten [9874.4, LA].

977. Trifolium medium L. - Vác: Gyadai-rétek, mezofil réteken, erdőszéleken [8180.4, LA].

984. Dorycnium herbaceum Vill. - Erdőbénye: Meszes-tisztás [7794.3, MCs]; Korlát: Kővágó

[7693.1, MCs]; Nagytarcsa: Küdői-hegy [8481.4, MCs]; Tápióság: Pándi-hegy [8683.2, MCs].

988. Lotus tenuis Waldst. et Kit. - Vértesszőlős: Által-ér melléke, mocsárréteken [8376.3, LA].

1003. Oxalis stricta L. - Gömörszőlős: belterület, virágágyásban [7688.2, MCs].

1004. Oxalis corniculata L. - Nyékládháza: belterület [8091.1, SK]; Veresegyház: útszéli gyomnövényzetben [8381.2, LA].

1005. Oxalis dillenii Jacq. - Szendrő: Kis-hegy, tarlón [7690.1, MCs].

1008. Geranium phaeum L. - Sirok: Nagy-Várhegy Ny-i lába [8087.3, MCs]; Tarcal: Rókadűlő [7894.3, MCs]; Tokaj: Hársas [7894.3, MCs]; Verpelét: Szederjes-tető [8186.2, MCs].

1009. Geranium sanguineum L. - Monok: Ingvár [7792.4, MCs]; Sárospatak-Végardó: Somlyód [7695.2, MCs].

1010. Geranium palustre E. Torner - Bercel-Csobánkapuszta: a Bér-patak völgyében, a tónál, magaskórósban [8182.2, LA]; Sátoraljaújhely: Rettel-dűlő [7695.2, MCs].

1011. Geranium pratense L. - Acsa: Sikár-tó, tóparti magaskórósban [8182.3, LA, LVD].

1015. Geranium dissectum Jusl. - Vilyvitány: szántókon [7595.1, MCs].

1025. Erodium ciconium (Jusl.) L’Hér. - Kunszentmárton-Kungyalu: Kungyalu vasúti megállóhely [9087.4, NT, TA]; Tihany: Gödrös, levendulaültetvény gyomnövényzetében [9073.3, LA, KA].

1026. Tribulus terrestris L. - Bánréve: vasútállomás [7788.1, MCs]; Hét: Pogonyipuszta vasúti megállóhely [7788.1, MCs]; Putnok: vasútállomás [7788.2, MCs]; Veresegyház: taposott gyomnövényzetben [8381.2, LA].

1027. Linum catharticum L. - Pánd: Hársas-völgy [8683.4, MCs].

1030. Linum flavum L. - Erdőbénye: Dió-kút [7794.1, MCs]. 
1031. Linum tenuifolium L. - Lőrinci: Mulató [8284.3, MCs]; Nagytarcsa: Küdői-hegy [8481.4, MCs].

1032. Linum hirsutum L. - Bercel: Farkasberek-puszta [8182.2, MCs]; Bercel: Mityiri-hegy [8182.1, MCs].

1034. Linum austriacum L. - Monok: Zsebrik alja, Borjú-völgy felé [7792.4, MCs].

1035. Linum perenne L. - Vácrátót: Tece, zárt homoki sztyeppréten [8381.1, LA].

1037. Mercurialis annua L. - Vértesszőlős: szántóföldi és kapás gyomtársulásokban [8376.3, LA].

1042. Euphorbia maculata L. - Füzesabony: vasútállomás, taposott gyomnövényzetben [8288.1, LA]; Nagyhegyes: Kossuth utca [8494.3, SK]; Veresegyház: Budapesti út, Fő tér, taposott gyomnövényzetben [8381.2, LA].

1044. Euphorbia helioscopia L. - Veresegyház: Ligetek, útszéli és szántóföldi gyomnövényzetben [8381.2, LA].

1045. Euphorbia platyphyllos L. - Szendehely: Kapáskúti-patak völgyében, útszéli rézsűkön [8180.2, LA].

1048. Euphorbia seguieriana Neck. - Bekecs: Nagy-hegy [7893.1, MCs]; Legyesbénye: Fulóhegy [7892.2, MCs]; Pécel: Száraz-hegy [8582.1, MCs]; Szada: homoki gyepekben [8381.2, 8381.4, LA].

1049. Euphorbia glareosa Pall. - Lőrinci: Mulató, egykori út mezsgyéjén [8284.3, MCs].

1052. Euphorbia epithymoides L. - Bekecs: Nagy-hegy [7893.1, MCs]; Legyesbénye: Fulóhegy [7892.2, MCs].

1058. Euphorbia salicifolia Host - Hernádnémeti: Harangod-halom és a mellette lévő mezsgye [7992.1, MCs]; Monok: Zsebrik Ny-i oldalában, felhagyott gyümölcsösben [7792.4, MCs]; Vác: Gyadai-rétek, üde és félszáraz gyepekben [8180.4, LA].

1061. Euphorbia esula L. - Őrbottyán: a Tece-patak forrásánál, mezofil réten [8381.1, LA].

1062. Euphorbia virgata Waldst. et Kit. - Gyöngyöshalász: a vasútállomástól K-re induló út mentén [8285.4, MCs]; Monok: Zsellér-part Ny-i völgye és Zsebrik Ny-i oldalában, felhagyott gyümölcsösben [7792.4, MCs]; Szegilong: Erdőbénye vasútállomás [7794.3, MCs]; Tápióbicske: Agyagásó [8684.1, MCs].

1064. Euphorbia peplus L. - Alsópetény: útszéleken [8181.1, LA]; Bánréve: belterület, járdarepedésben [7788.1, MCs]; Debrecen: a városban többfelé, például Nyíl u., Ibolya u. stb. [8495.4, TA]; Nagyhegyes: temető [8494.3, SK]; Tatabánya: Ifjúmunkás útja, virágágyásokban gyom [8476.1, LA]; Visegrád: Nagy-Villám Vadászcsárda, virágágyásokban gyom [8279.2, LA].

1065. Euphorbia exigua L. - Karcag: az Apavári-erdőtől Ny-ra, a 4-es út mentén, belvizes szántón [8691.4, NT, TA].

1068. Euphorbia falcata L. - Apc: Miskolc [8284.1, MCs].

1070. Dictamnus albus L. - Egerszalók: a víztározótól Ny-ra lévő erdőben [8187.2, MCs]; Hort: Cseplye [8284.4, MCs].

1074. Polygala major Jacq. - Apc-Rózsaszentmárton-Szücsi: Tarcod [8184.3, MCs]; Bercel: Berceli-hegy lába [8182.2, MCs]; Boldogkőújfalu: Falu-hegy és Fekete-hegy [7693.4, MCs]; Gyöngyöspata: Havas déli lába [8184.4, MCs]; Tállya: a Vár-hegytől ÉNy-ra lévő parlagokon, a Hollós-tető nyúlványán [7793.4, MCs].

1076. Polygala comosa Schkuhr - Bükkszentkereszt: Lófő-tisztás, mezofil és sovány gyepekben [7989.4, LA]; Miskolc: Nagy-mező, mezofil gyepekben [7989.1, LA]; Nagyvisnyó-Szilvásvárad: Nagy-mező és a környéke, mezofil gyepekben [7988.2, LA]; Répáshuta: falu, sovány gyepben [7989.3, LA].

1081. Cotinus coggygria Scop. - Monok: a falutól D-re, a szerencsi út mentén, árokban kivadulás [7892.2, MCs].

1082. Acer negundo L. - Tatabánya: ruderális élőhelyeken [8476.1, LA]. 
1083. Acer tataricum L. - Megyaszó: Hernád-magaspart, bozótosban [7792.3, MCs]; Novajidrány: Felsőnovaji-erdő [7592.4, MCs].

1086. Acer pseudoplatanus L. - Csécse: Bélahalom-puszta [8183.2, MCs].

1087. Acer platanoides L. - Novajidrány: Felsőnovaji-erdő [7592.4, MCs].

1090. Impatiens parviflora DC. - Erdőbénye: Király-kert [7794.1, MCs]; Magyarnándor: Réz-part, gyertyános-tölgyesben [8082.1, LA, LVD]; Monok: Szentes alja [7793.3, MCs].

1092. Impatiens balfourii Hook. - Esztergom: Cserepes-völgy [8278.4, CsM]. Árnyas patakparton, elegyes bükkös alatt, hordalékon néhány tő.

1097. Euonymus verrucosus Scop. - Csécse: Bélahalom-puszta [8183.2, MCs]; Nagyréde: Cseres [8284.2, MCs].

1098. Staphylea pinnata L. - Sirok: Nagy-Várhegy északi letörése [8087.3, MCs].

1100. Rhamnus catharticus L. - Gömörszőlős: Csató bérce [7688.2, MCs].

1117. Malva sylvestris L. - Veresegyház: útszéli gyomnövényzetben [8381.2, LA].

1119. Malva neglecta Wallr. - Veresegyház: útszéli gyomnövényzetben [8381.2, LA].

1124. Althaea cannabina L. - Nógrádsáp: Malom-dűlő [8182.1, MCs]; Pilisborosjenő: az „Egri vár" környékén, bolygatott szárazgyepben [8379.4, LA].

1127. Alcea biennis Winterl - Tihany: Külső-tó mellett [9073.3, MCs].

1129. Abutilon theophrasti Medik - Gömörszőlős: belterületen [7688.2, MCs].

1130. Hibiscus trionum L. - Szendrő: Kis-hegy, szántókon, parlagokon [7690.1, MCs]; Szendrő-Szuhogy: a két települést összekötő műút mentén [7690.1, MCs]; Veresegyház: útszéli és szántóföldi gyomnövényzetben [8381.2, LA].

1135. Thymelaea passerina (L.) Coss. et Germ. - Erdőhorváti: Haraszt-tisztás [7694.3, MCs]; Felsőtold: Bátor-lapos [8083.2, MCs]; Gömörszőlős: Csató bérce [7688.2, MCs]; Mátraszőlős: Garáb-nyereg és Zsák-fa között [8083.2, MCs].

1136. Hippophaë rhamnoides L. - Veresegyház: Álomvölgyi-víztározó környéke, homokbánya [8381.4, LA]. Feltehetően kivadulásból száramzó, adventív állomány.

1142. Hypericum tetrapterum Fr. - Veresegyház: Malomköz, bolygatott mocsári növényzetben [8381.2, LA].

1145. Hypericum hirsutum L. - Aldebrő: Cser [8187.3, MCs].

1147. Hypericum montanum L. - Szegi: Pécsi-tető [7794.3, MCs].

1156. Viola mirabilis L. - Aldebrő: Cser, leromlott állapotú gyertyános-kocsányos tölgyesben [8187.3, MCs]; Buják: Selyemrét [8183.1, MCs]; Egerszalók: a víztározótól Ny-ra lévő erdőben [8187.2, MCs]; Egerszólát: Ádám-tető [8187.2, MCs]; Erdőbénye: Király-kert [7794.1, MCs]; Harsány: Hársas-tető erdeje [8090.1, MCs]; Hidasnémeti: Nagy-erdő [7493.3, MCs]; Monok: Henc [7893.1, MCs].

1158. Viola hirta L. - Gyöngyöspata-Gyöngyöstarján: Gereg-hegy [8184.4, MCs]; Gyöngyöstarján: Nagy-Kocsordos [8184.4, MCs]; Gyöngyöstarján: Gereg-hegy [8185.3, MCs]; Hort: Cseplye [8284.4, MCs]; Nagyréde: Cseres [8284.2, MCs]; Novajidrány: Felsőnovaji-erdő [7592.4, MCs]; Vilyvitány: Girától É-ra [7495.3, MCs].

1159. Viola ambigua Waldst. et Kit. - Albertirsa: Lipina- és Hársas-erdő [8783.2, MCs]; Legyesbénye: Fuló-hegy [7892.2, MCs].

1160. Viola rupestris F.W. Schmidt - Tata: Réti-malom, homoki sztyeppréten [8375.2, LA].

1161. Viola reichenbachiana Jord. - Nagyréde: Cseres [8284.2, MCs].

1162. Viola riviniana Rchb. - Mikóháza: Nagy-Polyán melletti rontott erdőkben [7595.2, 7595.4, MCs].

1163. Viola elatior Fr. - Cserhátszentiván: Kecske-hát [8083.1, MCs]; Gyöngyös: Sár-hegy, a csúcs körüli melegkedvelő tölgyesben [8285.2, MCs]; Nagyréde: Cseres [8284.2, MCs]; Pásztó: Kerek-domb [8184.1, MCs]; Tatabánya: Bika-rét, gyomos erdei tisztáson [8476.2, LA].

1164. Viola canina L. - Gyöngyössolymos: Kis-hegy [8185.4, MCs]. 
1164.2. Viola canina L. subsp. montana (L.) Hartm. - Szendrő: Kis-hegy, erdei út mentén [7690.1, MCs].

1165. Viola pumila Chaix - Egerszólát: Ádám-tető [8187.2, MCs]; Legyesbénye: Fuló-hegy [7892.2, MCs].

1169. Helianthemum ovatum (Viv.) Dunal in DC. - Kerecsend: Lógó-part [8288.1, MCs].

1175. Elatine alsinastrum L. - Berettyóúifalu-Berettyószentmárton: Vancsodi-dűlő [8895.4, MVA]; Felsőregmec: Izra-tó [7595.2, MCs].

1176. Elatine hungarica Moesz - Karcag: az Apavári-erdőtől Ny-ra, a 4-es út mentén [8691.4, NT, TA]; Makó-Rákos: Vékony-ér [9789.1, NT, TA]; Nagymágocs: a telpülés D-i szélén [9488.2, NT, TA]. Valamennyi helyen belvizes szántón.

1178. Elatine triandra Schkuhr - Karcag: az Apavári-erdőtől Ny-ra, a 4-es út mentén, belvizes szántón [8691.4, NT, TA].

1180. Thladiantha dubia Bunge - Debrecen: a Bajcsy-Zsiliszky út 15-17. számnál nyíló parkoló gyomos szegélyében [8495.4, SK].

1194. Peplis portula L. - Karcag: az Apavári-erdôtől Ny-ra, a 4-es út mentén, belvizes szántón [8691.4, NT, TA]; Mád: Bomboly mellett, útszélen [7793.4, MCs]; Sirok: Nagy-Paska [8087.3, MCs].

1197. Lythrum hyssopifolia L. - Bőcs: Nagy-Szög, belvizes szántón [7991.4, NT, TA]; Karcag: az Apavári-erdőtól Ny-ra, a 4-es út mentén, belvizes szántón [8691.4, NT, TA].

1198. Lythrum tribracteatum Salzm. in Spreng. - Makó-Rákos: Vékony-ér [9789.1, NT, TA]; Nagymágocs: a telpülés D-i szélén [9488.2, NT, TA]. Mindkét helyen belvizes szántón.

1203. Trapa natans L. - Tihany: Tihanyi-móló [9073.3, SK].

1226. Epilobium ciliatum Raf. - Veresegyház: Malomköz, nedves gyomtársulásokban [8381.2, LA].

1228.2. Epilobium tetragonum L. subsp. lamyi (Schultz) Nyman - Szendrő: Kis-hegy, tarlón [7690.1, MCs].

1233. Cornus mas L. - Nagyréde: Cseres [8284.2, MCs].

1241. Sanicula europaea L. - Gömörszőlős: Kolyota, Pincék oldali erdő [7688.2, MCs].

1242. Astrantia major L. - Miskolc: Jávorkút, erdei vágásnövényzetben [7989.1, LA, LVD]; Mogyoróska: Fekete-patak mellett [7693.2, MCs].

1244. Eryngium planum L. - Erdőhorváti: Szőlő-mál-tető és Vár-kúti-rét [7694.3, MCs]; Felsőregmec: Nád-kút kis rétje és a környező földutak mente [7595.2, MCs]; Kazincbarcika: Sinka-hegy és Vár-hegy között [7789.4, MCs].

1251. Anthriscus caucalis M. Bieb. - Debrecen: Nyugati utca [8495.4, SK]; Makó-Rákos: Vékony-ér [9789.1, NT, TA].

1257. Bifora radians M. Bieb. - Szanda: Határok, repcevetésben [8082.4, LA, LVD]; Vác: Egyházmöge, vetésekben [8180.4, LA]; Veresegyház: Tavi Panzió, virágládákban gyom [8381.4, LA].

1262. Aegopodium podagraria L. - Szendrő: Vásártértől D-re lévő egykori Bódva meder mentén és Billér-hegy [7690.1, MCs].

1265. Berula erecta (Huds.) Coville - Szalonna: Köszvényes-kút [7590.1, SK].

1266. Libanotis pyrenaica (L.) Bourg. - Sirok: Vár [8087.3, MCs]; Szalonna: Köszvényes-kút [7590.1, SK]; Szendrő: Kis-hegy, erdőszélen, földút mentén [7690.1, MCs].

1268. Seseli hippomarathrum Jacq. - Fót: Somlyó, szárazgyepekben [8381.3, LA].

1275. Oenanthe silaifolia M. Bieb. - Jászdózsa: Vágó-járás, hernyópázsitos gyepben [8486.1, SK].

1277. Aethusa cynapium L. - Gömörszőlős: belterületen [7688.2, MCs]; Szalonna: Perkupa

felé, a Bódva bal partján, parlagon hagyott szántó nedves szegélyében [7590.1, SK].

1284. Bupleurum rotundifolium L. - Bercel: Farkasberek-puszta [8182.2, MCs].

1287. Bupleurum tenuissimum L. - Mezőzombor: Fecskés, felhagyott faluszéli legelőn [7893.3, MCs]. 
1291. Bupleurum affine Sadler - Pánd: Hársas-völgy [8683.4, MCs].

1292. Bupleurum pachnospermum Pančić - Bodrogkisfalud: Vár-hegy, szórványosan a tető körüli gyepekben [7894.1, MCs].

1294. Trinia ramosissima (Fisch.) W.D.J.Koch - Abaújalpár: Aranyos felé lévő hegy [7693.3, MCs]; Pásztó: Gombás-tető (volt repülőtér) [8084.4, MCs].

1298. Cicuta virosa L. - Veresegyház: Malom-tó, alkalmilag a Sződrákosi-patakon is, úszó nádszigeteken, nádasokban, vízpartokon gyakori [8381.4, LA].

1300. Carum carvi L. - Tahitótfalu: Zánkói-rét, Vértes-mező, mezofil réteken [8280.3, LA].

1301. Cnidium dubium (Schkuhr) Thell. - Tatárszentgyörgy: Szabadrét [8981.2, NT, TA, MVA].

1302. Selinum carvifolia L. - Gyöngyössolymos: Kis-hegy [8185.4, MCs]; Hidasnémeti: Perényi-szőlők [7493.3, MCs].

1309. Peucedanum carvifolia Vill. - Kárász: Petrőc, mezofil réten [9775.2, LA]; Kisbeszterce: Pusztaszőlősi-gödör, mezofil réten [9774.3, LA].

1311. Peucedanum officinale L. - Sárospatak-Végardó: Somlyód [7695.2, MCs]; Szegilong: Pécsi-tető keleti lejtője, felhagyott szőlőben [7794.3, MCs].

1312. Peucedanum alsaticum L. - Boldogkőúffalu: Kőtenger [7693.3, MCs]; Boldogkőújfalu: Falu-hegy és Fekete-hegy [7693.4, MCs]; Feldebrő: Cser [8187.3, MCs].

1313. Peucedanum palustre (L.) Moench - Fony: Nagy- és Kis-Dinnyés-tó, valamint Szárkő-rét [7593.4, MCs].

1314. Peucedanum cervaria (L.) Lapeyr. - Sárospatak-Végardó: Somlyód [7695.2, MCs].

1315. Peucedanum oreoselinum (L.) Moench - Erdőbénye: Palánkos [7794.1, MCs]; Erdőhorváti: Dóka-rét [7794.1, MCs]; Kisújszállás: Nagyerdő [8790.3, MCs]; Pánd: Hársasvölgy, mezsgyén [8683.4, MCs]; Sárospatak: Páncél-hegy [7695.3, MCs]; SárospatakVégardó: Somlyód [7695.2, MCs].

1320. Tordylium maximum L. - Abaújszántó: Sátor-hegy [7793.1, TA]; Buják: Agyagos-dűlő, parlagokon [8183.1, LA]; Gyöngyöstarján: Gereg [8185.3, MCs]; Tállya: Patócs-hegy [7793.3, MCs].

1321. Laser trilobum (L.) Borkh. - Sirok: Kis-Várhegy D-i oldala [8087.3, MCs].

1323. Laserpitium latifolium L. - Parád: Som-hegy [8086.3, MCs].

1325. Torilis japonica (Houtt.) DC. - Nagyréde: Cseres [8284.2, MCs].

1327. Caucalis platycarpos L. - Abaújszántó: Sátor-hegy, déli oldal, bokorerdőben [7793.1, MCs]; Apc: Miskolc [8284.1, MCs]; Felsőtold: Major-hegy [8083.2, MCs].

1335. Orthilia secunda (L.) House - Répáshuta: Balla-bérc, bükkösben [7989.3, LA, LVD].

1340. Calluna vulgaris (L.) Hull - Erdőhorváti: Páca-fark [7694.3, MCs].

1343. Vaccinium vitis-idae L. - Makkoshotyka: Dobogó-tető [7695.1, MCs].

1351. Androsace elongata L. - Legyesbénye: Fuló-hegy [7892.2, MCs]; Monok: Zsebrik Ny-i oldalában, felhagyott gyümölcsösben [7792.4, MCs]; Sárospatak-Végardó: Somlyód [7695.2, MCs].

1363. Samolus valerandi L. - Pétfürdő: belterület, a Csónakázó tó mellett [8874.2, MA, MVA].

1375. Fraxinus excelsior L. - Szada: Margita [8381.4, MCs].

1377. Syringa vulgaris L. - Bodrogkisfalud: Vár-hegy, inváziós [7894.1, MCs]; Veresegyház: Ligetek, mezsgyéken [8381.2, LA].

1378. Ligustrum vulgare L. - Veresegyház: Ligetek, bolygatott erdőkben, cserjésekben [8381.2, LA].

1384. Gentiana cruciata L. - Mátramindszent-Mátraterenye: Alsóivánpuszta mellett [8085.2, MCs]; Regéc: Dabróka-dűlő, parlagon [7693.2, MCs]; Rimóc: Fekete-hegy lába, Mengyi-szállás felé [8083.2, MCs].

1385. Gentiana pneumonanthe L. - Baskó: Bika-rét [7694.3, MCs].

1392. Vinca herbacea Waldst. et Kit. - Abaújszántó: Sátor-hegy, déli oldal, bokorerdőben [7793.1, MCs]; Hort: Cseplye [8284.4, MCs]; Ozora: temető, bolygatott száraz gyepben $[9276.3, \mathrm{LA}]$. 
1393. Vinca minor L. - Aszaló: Erdők széle, kontinentális erdősszytepp-erdő aljnövényzetében [7791.4, MCs]; Hidasnémeti: Nagy-erdő [7493.3, MCs]; Szendrő: Billér-hegy [7690.1, MCs].

1395. Asclepias syriaca L. - Felsőtold: Hegymeg, Sándortanyától É-ra, Major-hegy lába [8083.2, MCs]; Gyöngyöshalász: a halastótól É-ra, szántón [8285.4, MCs]; Mátraszőlős: Sátor-hegy és Kerek-bükk közötti tisztás [8084.1, MCs]; Monok: Hosszú-hegy Ingvár felöli sarkán, régi mezsgyében [7892.2, MCs]; Sajógalgóc: a vasúti töltés mentén Dubicsány felé [7789.1, MCs]; Szegilong: Erdőbénye vasútállomás [7794.3, MCs]; Taktaszada: a vasúti töltés mentén Taktaharkány felé [7892.4, MCs].

1396. Vincetoxicum hirundinaria Medik. - Nagyréde: Cseres [8284.2, MCs]; Nagytarcsa: Küdői-hegy [8481.4, MCs].

1410. Heliotropium europaeum L. - Apc: 21-es pihenő, kamion-parkoló [8284.1, MCs]; Kiskunhalas: Latabár utca [9582.2, SK]; Nógrádkövesd: Száraz-tó [8182.1, MCs]; Pánd: Hársas-völgy, parlagon [8683.4, MCs]; Tarnaméra: temető [8386.4, SK]; Tihany: Külső-tó mellett [9073.3, MCs]; Veresegyház: Ligetek, ruderális gyomnövényzetben [8381.2, LA]; Vértesszőlős: Alsó-rétek, belvizes szántón [8376.3, LA].

1412. Lithospermum officinale L. - Legyesbénye: Lete-erdőtől D-re, szőlők mellett [7892.2, MCs]; Verpelét: Túró-mező [8187.1, MCs].

1414. Buglossoides arvensis (L.) I.M.Johnstone - Legyesbénye: Fuló-hegy Ny-i oldala [7892.2, MCs].

1416. Onosma arenaria Waldst. et Kit. - Sajóvelezd: Lapos-kő [7788.2, MCs].

1418. Cerinthe minor L. - Bénye: közvetlenül a falutól D-re és Lomen-völgy [8683.3, MCs]; Gyöngyöshalász: Szent Karmellus kápolna mellett [8285.2, MCs]; Gyöngyöspata: Kovaföldbánya [8184.3, MCs]; Visonta: Bajusz-dúlő [8285.2, MCs].

1422. Echium maculatum L. - Buják: Sár-hegy és Sas-hegy [8083.3, MCs].

1423. Pulmonaria obscura Dumort. - Egerszalók: a víztározótól Ny-ra lévő erdőben [8087.4, MCs]; Garadna: Nagy-völgy [7592.4, MCs].

1426. Pulmonaria mollissima A.Kern. - Nagyréde: Cseres [8284.2, MCs].

1427. Nonea lutea (Desr.) DC. - Pannonhalma: apátsági major, levendulaültetvény gyomnövényzetében [8472.2, LA].

1428. Nonea pulla (L.) DC. - Abaújszántó: Bűdi-járó, mezsgyében [7793.1, MCs]; Hort: Cseplye [8284.4, MCs]; Ragály: temető [7589.3, SK].

1429. Symphytum tuberosum L. - Monok: Nyírjes és Falu gaza-hegy között [7892.2, MCs]; Pannonhalma: erdőfolt a 82121-es út mellett, [8472.4, LA].

1434. Lycopsis arvensis L. - Tata: Réti-malom környéke, fenyőültetvény szegélyében [8375.2, LA].

1440. Asperugo procumbens L. - Csécse: Alsó-rétek, Bélahalom-puszta [8183.2, MCs]; Ecseg-Pásztó: Hosszú-völgy [8183.2, MCs]; Kisújszállás: Nagyerdő [8790.3, MCs]; Legyesbénye: Lete-erdőtől D-re, szőlők mellett [7892.2, MCs]; Mátraszőlős-Pásztó: Tégladomb [8084.3, MCs].

1443. Myosotis nemorosa Besser - Fony: Szár-kő-rét [7593.4, 7594.3, MCs].

1447. Myosotis stricta Link - Őrbottyán: Alsó-rétek, bolygatott homoki gyepekben [8381.1, LA]; Őrbottyán: Kenderföldek, bolygatott homoki gyepekben [8381.2, LA].

1449. Myosotis sparsiflora J.G.Mikan - Aldebrő: Cser [8187.3, MCs]; Magyarnándor: Rézpart, gyertyános-tölgyesben [8082.1, LA]; Pécsvárad: Dombay-forrás, üde, bolygatott aljövényzetben [9876.3, LA]; Vácrátót: Sződrákosi-patak mentén, akácosban [8281.3, LA].

1456. Lappula heteracantha (Ledeb.) Borbás - Tállya: Patócs-hegy [7793.3, MCs].

1460. Cynoglossum hungaricum Simonk. - Tarnabod: a községhatár K-i részén fekvő bányatavak körül [8387.2, NT, TA]. 
1461. Phacelia tanacetifolia Benth. - Szurdokpüspöki: a 21 út mentén, vetik és kivadul [8184.1, MCs]; Veresegyház: Haldorádó-horgásztó töltésén, építkezés utáni bolygatott felszínen [8381.4, LA].

1473. Ajuga genevensis L. - Bekecs-Taktaszada: vasútmezsgyén [7893.3, MCs]; Hernádnémeti: Újsiskától nyugatra lévő út mezsgyéje [7992.1, MCs]; Megyaszó: Kis-erdő mellett [7892.1, MCs].

1474. Teucrium botrys L. - Pilisborosjenő: Nagy-Kevély, árnyas (elbányászott?) sziklafelszín másodlagos pionír gyepében [8379.4, LA]. Mennyisége évről évre a néhánytól a többszáz példányig változó.

1475. Teucrium montanum L. - Bercel: Mityiri-hegy [8182.1, MCs]; Bercel: Farkasberekpuszta [8182.2, MCs]; Nagytarcsa: Küdői-hegy [8481.4, MCs]; Nógrádsáp: Malom-dúlő [8182.1, MCs].

1478. Teucrium scordium L. - Jobbágyi-Zagyvaszántó: Szuha-patak mente [8183.4, MCs].

1482. Scutellaria altissima L. - Gyöngyöspata: Csárda-puszta [8184.3, MCs]; Pásztó: Muzslai üdülőtől D-re, völgyaljban [8184.1, MCs].

1484. Marrubium peregrinum L. - Boldogkőváralja: Pukkanc-tanya mellett [7693.3, MCs].

1486. Sideritis montana L. - Bercel: Farkasberek-puszta [8182.2, MCs]; Tápióbicske: Agyagásó [8684.1, MCs].

1510. Stachys sylvatica L. - Egerszalók: a víztározótól Ny-ra lévő erdőben [8187.2, MCs]; Hatvan-Kisgombos: Legelőerdő, felhagyott, cserjésedő fáslegelőn [8284.3, MCs]; Novajidrány: Felsőnovaji-erdő [7592.4, MCs].

1516. Nepeta pannonica L. - Regéc: Dabróka-dúlő [7693.2, MCs].

1517. Nepeta cataria L. - Lőrinci: Mulató [8284.3, MCs].

1522. Prunella laciniata L. - Nagytarcsa: Küdői-hegy [8481.4, MCs]; Pánd: Hársas-völgy [8683.4, MCs].

1524. Prunella grandiflora (L.) Scholler - Bercel: Mityiri-hegy [8182.1, MCs]; Erdőhorváti: Páca-fark, Hárs-kúti-rét és Bagoly-rét [7694.3, MCs].

1528. Calamintha menthifolia Host - Dédestapolcsány: Nagy-erdő [7888.2, MCs]; Sirok: Darnó-hegy [8087.3, MCs]; Sirok: Nagy-Várhegy [8087.3, MCs]; Sirok-KőkútTarnaszentmária: Bóna-halom 396,5 m-es csúcsa [8187.1, MCs].

1536. Thymus pulegioides L. - Miskolc-Nagyvisnyó: Nagy-mező, mezofil réteken, sovány gyepekben [7989.1, 7988.2, LA]; Okorvölgy: Szabadságmajor, mezofil réten [9874.1, LA]; Terény: Bocsokpuszta, 278 m-es domb, mezofil legelőn [8082.4, LA]; Vác: Gyadai-rétek, mezofil réten $[8180.4, \mathrm{LA}]$.

1556. Salvia verticillata $\mathrm{L}$. - Gömörszőlős: belterület [7688.2, MCs].

1557. Salvia glutinosa L. - Sirok-Kőkút: Bóna-völgy [8187.1, MCs].

1559. Salvia aethiopis L. - Mátraszőlős-Pásztó: Tégla-domb [8084.3, MCs]; Pánd: Hársasvölgy [8683.4, MCs].

1560. Salvia austriaca Jacq. - Ecséd: Ágói-patak löszvölgye a falu alatt [8284.4, MCs]; Monok: Oláh-völgy, valamint a Gilip-patak és Tetétlen közötti legelőn [7792.4, MCs]; Pécel: Száraz-hegy [8582.1, MCs].

1571. Hyoscyamus niger L. - Tarnaörs: a Tarna gátoldalában [8486.1, SK].

1572. Physalis alkekengi L. - Megyaszó: Hernád-magaspart, bozótosban [7792.3, MCs]; Nógrádsáp: Malom-dűlő [8182.1, MCs]; Tápióság: Pipa-hegy és Pándi-hegy közötti mezsgye [8683.2, MCs].

1591. Lindernia procumbens (Krock.) Philcox - Karcag: az Apavári-erdőtől Ny-ra, a 4-es út mentén, belvizes szántón [8691.4, NT, TA].

1593. Limosella aquatica L. - Bőcs: Nagy-Szög [7991.4, NT, TA]; Karcag: az Apavári-erdőtől Ny-ra, a 4-es út mentén [8691.4, NT, TA]. Mindkét esetben belvizes szántón.

1596. Verbascum blattaria L. - Girincs: Pap-föld, árok mezsgyéjében [8091.2, MCs]. 
1597. Verbascum chaixii Vill. subsp. austriacum (Schott) Hayek - Gesztely: az újharangodi út mezsgyéje [7892.3, MCs].

1611. Misopates orontium (L.) Rafin. - Dunabogdány: kőbánya, útszéli gyomnövényzetben [8280.1, LA]; Erdőtarcsa: Halász-dűlő [8283.1, MCs]; Olaszliszka: Rakottyás, Csontos [7794.1, MCs].

1612. Microrrhinum minus (L.) Fourr. - Budapest: Arany János utca, metroállomás, útszéli gyomnövényzetben [8480.3, LA]; Herencsény: Szentiványi műút mellett [8083.1, MCs]; Nagyhegyes: temető [8494.3, SK]; Nógrádkövesd: vasútállomás [8182.1, MCs]; Ózd: buszpályaudvar [7787.4, MCs]; Pánd: Hársas-völgy, vetett gyepben [8683.4, MCs]; Szegilong: Erdőbénye vasútállomás [7794.3, MCs].

1614. Linaria genistifolia (L.) Mill. - Erdőbénye: Mulató [7794.1, MCs].

1615. Linaria angustissima (Loisel.) Borbás - Pánd: Hársas-völgy [8683.4, MCs].

1617. Linaria biebersteinii Besser subsp. strictissima (Schur) Soó - Gyöngyöstarján: Hosszú-hegy és Gereg [8184.4, 8185.3, MCs]; Monok: Hosszú-völgy [7792.4, MCs]; Tállya: Palota-hegy [7793.3, MCs].

1619. Kickxia spuria (L.) Dumort. - Cserháthaláp: Tornyos-hegy környéke, bolygatott szárazgyepekben [8082.1, LA]; Erdőbénye: Magita, parlagon [7794.1, MCs]; Pánd: Hársasvölgy, vetett gyepben [8683.4, MCs].

1620. Kickxia elatine (L.) Dumort. - Budapest: ELTE TTK kampusz, útszéli gyomnövényzetben [8580.1, LA]; Mátraszőlős: Garáb-nyereg és Zsák-fa között [8083.2, MCs]; Nagyhegyes: a település szélén, üres telken [8494.3, SK]; Tarnaörs: a Tarna gátoldalában [8486.1, SK]; Tihany: Rátai-csáva [9073.3, MCs]; Verpelét: Túró-mező és Oszlások [8187.1, MCs].

1625. Pseudolysimachion longifolium (L.) Opiz - Kutasó: Kutasói elágazás mellett [8083.1, MCs]; Olaszliszka: erdőbényei út mellett [7794.3, MCs]; Szegilong: Meszes [7794.3, MCs].

1635. Veronica anagallis-aquatica L. - Makó-Rákos: Vékony-ér [9789.1, NT, TA]; Nagymágocs: a telpülés D-i szélén [9488.2, NT, TA]. Mindkét esetben belvizes szántón.

1639. Veronica teucrium L. - Gyöngyössolymos: Kis-hegy [8185.4, MCs].

1644. Veronica triphyllos L. - Aldebrő: Cseri őrház tisztásán [8187.3, MCs]; Veresegyház: száraz homoki gyepekben, szántókon [8381.2, 8381.4, LA].

1646. Veronica dillenii Crantz - Veresegyház: Ivacsi-tó mellett, bolygatott homoki gyepben [8381.4, LA].

1647. Veronica serpyllifolia L. - Kisújszállás: Nagyerdő [8790.3, MCs]; Szászfa: temető [7591.2, MVA, SK]; Veresegyház: szárazgyepekben [8381.2, LA].

1648. Veronica arvensis L. - Monok: Ingvár-tótól D-re, szántón [7892.2, MCs].

1650. Veronica praecox All. - Veresegyház: száraz homoki gyepekben, szántókon [8381.2, 8381.4, LA].

1652. Veronica triloba (Opiz) Wiesb. - Őrbottyán: száraz homoki gyepben, szántókon [8381.2, LA].

1653. Veronica hederifolia L. s. str. - Veresegyház: gyomnövényzetben [8381.2, LA].

1656. Veronica persica Poir. - Veresegyház: gyomtársulásokban [8381.2, 8381.4, LA].

1658. Veronica polita Fr. - Sirok: Szalokma-völgy [8087.3, MCs]; Veresegyház: gyomtársulásokban [8381.2, LA].

1660. Melampyrum cristatum L. - Aszaló: Kút-völgyi út mellett [7791.4, MCs]; Bodrogkisfalud: Galambos [7794.3, MCs]; Boldogkőváralja: Rádi-máj [7693.3, MCs]; Erdőbénye: Meszes és Sötétes-tető közötti gyep, Meszes-tisztás [7794.3, MCs]; Pásztó: Széles-bükk [8084.4, MCs]; Szegilong: Hosszú-máj, Poklos [7794.3, MCs].

1662. Melampyrum barbatum Waldst. et Kit. - Hort: Cseplye [8284.4, MCs]; Sirok: Ördögvölgy [8087.3, MCs].

1668. Euphrasia stricta Wolf - Erdőbénye: Ösztvér [7794.1, MCs]. 
1670. Odontites lutea (L.) Clairv. - Erdőbénye: Mulató [7794.1, MCs]; Tolcsva: Határzugikút alatt [7694.4, MCs].

1671. Odontites vernus (Bellardi) Dumort. - Bénye: közvetlenül a falutól D-re és Lomen-völgy [8683.3, MCs]; Erdőbénye: Mulató [7794.1, MCs]; Veresegyház: Malomköz, üde gyomnövényzetben [8381.2, 8381.4, LA].

1674. Rhinanthus serotinus (Schönh.) Oborný - Mikóháza: Kis-Polyán, legelőn [7595.2, 7595.4, MCs]; Tata: Réti-malom környéki rétek, sztyepprét-láprét komplex [8375.2, LA].

1677. Rhinanthus rumelicus Velen. - Szokolya: Klöki-hegy, szántókon, felülvetett és bolygatott gyepekben [8179.2, LA].

1682. Globularia punctata Lapeyr. - Nagytarcsa: Küdői-hegy [8481.4, MCs].

1687. Orobanche purpurea Jacq. - Domoszló-Recsk: Jagus-bérc [8186.2, MCs].

1701. Orobanche caryophyllacea Sm. - Sárospatak: Mandulás [7695.3, MCs].

1718. Asperula cynanchica L. - Gesztely: az újharangodi út mezsgyéje [7892.3, MCs]; Köröm: műútmezsgye a határ ÉK-i részén [8091.2, MCs]; Tiszalúc: Sarkadi-legelő és a környező mezsgyék [7992.3, MCs].

1724. Galium rubioides L. - Eger-Felnémet: Kerek-domb [8088.3, MCs]; Vilyvitány: ElsőForduló területén lévő kis kiszáradó láprét foltban [7595.1, MCs].

1725. Galium rivale (Sibth. et Sm.) Griseb. - Szendrő-Szuhogy: Hideg-völgy, mocsárréten [7690.1, MCs].

1728. Galium glaucum L. - Buják: Henyelpuszta felett [8183.2, MCs].

1734. Galium uliginosum L. - Veresegyház: Malomköz, magaskórósok, nádasok, nedves szegélynövényzet [8381.2, LA].

1747. Cruciata pedemontana (Bellardi) Ehrend. - Vértesszőlős: Kovács-hegy lábainál, legeltetett száraz gyepeb [8376.3, LA].

1751. Plantago indica L. - Veresegyház: bolygatott homoki gyepekben [8381.2, LA].

1754. Plantago schwarzenbergiana Schur - Derecske: Kis-legelő [8695.2, MVA].

1756. Plantago lanceolata L. - Veresegyház: gyepekben, gyomtársulásokban [8381.2, LA].

1757. Plantago altissima L. - Tatárszentgyörgy: Szabadrét [8981.2, NT, TA, MVA].

1765. Viburnum Iantana L. - Visonta: meddőhányón, spontán [8286.1, MCs].

1770. Lonicera xylosteum L. - Lőrinci: Szurdok, a Petőfibánya-Rózsaszentmárton úttól D-re lévő mély völgy [8284.1, MCs].

1784. Cephalaria transsylvanica (L.) Schrad. - Herencsény: Palócok Vigyázó Keresztje [8082.2, MCs]; Szada: Székely Bertalan út, útszéli félruderális növényzetben [8381.4, LA].

1785. Dipsacus pilosus L. - Dédestapolcsány: Rádincs- és Miklós-völgy, valamint a Lázbércitározó mellett [7888.2, MCs]; Egerszalók: Alsó-rét, Laskó mente [8187.2, MCs]; Garadna: Nagy-völgy [7592.4, MCs]; Mátraballa: Balla-völgy [8085.2, MCs]; Szendrő: Vásártértől D-re lévő egykori Bódva meder mentén [7690.1, MCs]; Tállya: a Vár-hegytől ÉNy-ra, Ny-ra lévő árokban [7793.4, MCs].

1788. Succisa pratensis Moench - Erdőbénye: Meszes-tisztás [7794.3, MCs].

1797. Campanula glomerata L. - Boldogkőváralja-Hernádcéce: Aba-hegy [7693.3, MCs]; Korlát: Kővágó [7693.1, MCs]; Vizsoly: Kopros [7693.1, MCs].

1799. Campanula cervicaria L. - Egerszólát: Ádám-tető [8187.2, MCs]; Gyöngyöspata: Havas ÉNy-i lábánál lévő rét [8184.4, MCs]; Sátoraljaújhely: Tatárka-tisztás [7695.2, MCs]. 1800. Campanula sibirica L. - Bodrogkisfalud: Vár-hegy [7894.1, MCs].

1801. Campanula bononiensis L. - Boldogkőváralja-Hernádcéce: Aba-hegy [7693.3, MCs]; Korlát: Kővágó [7693.1, MCs]; Vizsoly: Kopros és a kőfejtő mellett [7693.1, MCs].

1802. Campanula rapunculoides L. - Nagyréde: Cseres [8284.2, MCs].

1804. Campanula trachelium L. - Nagyréde: Cseres [8284.2, MCs].

1805. Campanula persicifolia L. - Nagyréde: Cseres [8284.2, MCs]; Szendrő: Billér-hegy [7690.1, MCs]. 
1806. Campanula rapunculus L. - Lőrinci: Szurdok, a Petőfibánya-Rózsaszentmárton úttól D-re lévő mély völgy [8284.1, MCs].

1807. Campanula patula L. - Boldogkőváralja: Pukkanc-tanya mellett [7693.3, MCs]; Vizsoly: Kopros [7693.1, MCs].

1808. Campanula rotundifolia agg. - Abaújszántó-Abaújkér: Gyưr-tető oldala [7793.1, MCs].

1813. Asyneuma canescens (Waldst. et Kit.) Griseb. et Schenk - Abaújszántó: Szabadka [7793.1, MCs]; Abaújszántó-Abaújkér: Gyưr-tető és völgy [7793.1, MCs].

1823. Solidago gigantea Aiton - Dédestapolcsány: Rádincs, kiszálalt bükkösben [7888.2, MCs].

1828. Aster linosyris (L.) Bernh. - Boldogkőúffalu: Kőtenger [7693.3, MCs]; Boldogkőváralja-Hernádcéce: Aba-hegy [7693.3, MCs]; Korlát: Kővágó [7693.1, MCs].

1829. Aster sedifolius L. subsp. canus (Waldst. et Kit.) Merxm. - Erdőbénye: Ördög-kő-sor és Peres [7794.1, MCs]; Olaszliszka: Meszesmajor és Szegilong: Pécsi-tető keleti lejtője [7794.3, MCs]; Sárospatak-Végardó: Somlyód [7695.2, MCs]; Tállya: Dorgó alja [7793.4, MCs].

1831. Aster amellus L. - Olaszliszka: Sajgó [7794.1, MCs]; Tolcsva: Határzugi-kút alatt [7694.4, MCs].

1835. Aster ×salignus Willd. - Veresegyház: Álomvölgy-víztározó, homokbánya [8381.4, LA].

1841. Filago lutescens L. - Gömörszőlős: Egerdő-tető, parlagon [7688.2, MCs].

1842. Filago vulgaris L. s. str. - Hidasnémeti: Meggyes-dúlő [7493.3, MCs].

1843. Filago arvensis L. - Szegilong: Poklos [7794.3, MCs].

1846. Gnaphalium sylvaticum L. - Feldebrő: Cser-erdő lábánál [8187.3, MCs].

1847. Gnaphalium uliginosum L. - Bőcs: Nagy-Szög, belvizes szántón [7991.4, NT, TA]; Recsk: Recski határra járó dúlő [8186.2, MCs].

1850. Antennaria dioica (L.) Gaertn. - Pécs: Misina sípálya, sovány gyepben [9875.3, LA]; Pilisborosjenő: Fehér-hegy, dolomitkopárra ültetett feketefenyvesben [8379.4, LA]. Mindkét helyen egy-egy sarjtelep.

1851. Inula helenium L. - Jobbágyi-Zagyvaszántó: Szuha-patak mente [8183.4, MCs]; Mátraszőlős-Pásztó: Tégla-domb [8084.3, MCs]; Pásztó: Nagy-Cser [8183.2, MCs]; Terény: Hegy [8082.4, MCs].

1852. Inula conyza DC. - Atkár: gyöngyösi út menti parlagon [8285.3, MCs]; Feldebrő: Cser [8187.3, MCs]; Hort: Cseplye [8284.4, MCs].

1853. Inula hirta L. - Abaújszántó-Abaújkér: Gyưr-tető és völgy [7793.1, MCs]; Legyesbénye: Fuló-hegy [7892.2, MCs]; Monok: Hosszú-völgy, Oláh-völgy [7792.4, MCs].

1856. Inula germanica L. - Abaújszántó: Sátor-hegy, déli oldal, bokorerdőben [7793.1, MCs]; Tolcsva: Vár-hegy [7794.2, MCs].

1857. Inula salicina L. - Boldogkőújfalu: Falu-hegy és Fekete-hegy [7693.4, MCs]; Ecseg: Keresztvölgy-pusztától D-re lévő domb [8183.2, MCs]; Korlát: Kővágó [7693.1, MCs].

1858. Inula ensifolia L. - Abaújszántó-Abaújkér: Gyür-tető és völgy [7793.1, MCs]; Gyöngyöspata: Csárda-puszta [8184.3, MCs]; Korlát: Kővágó [7693.1, MCs]; Lőrinci: Mulató [8284.3, MCs]; Mátraszőlős-Pásztó: Tégla-domb [8084.3, MCs]; Nógrádsáp: Malom-dűlő [8182.1, MCs].

1860. Pulicaria vulgaris Gaertn. - Jászdózsa: Pincés-Kút-dúlő, földút mentén [8486.1, SK].

1885. Galinsoga ciliata (Raf.) S.F. Blake - Debrecen: Piac utca [8495.4, SK]; KemenceKirályháza: a turistaház mellett, üde gyomnövényzetben [8079.2, LA].

1893. Anthemis austriaca Jacq. - Gyöngyöshalász: a vasútállomástól K-re, napraforgótáblában [8285.4, MCs].

1897. Achillea crithmifolia Waldst. et Kit. - Nógrádsipek: Földvár [8083.1, MCs]; Terény: Káposztás-hegy [8082.4, MCs].

1911. Matricaria recutita L. - Gömörszőlős: belterületen, taposott udvarokon [7688.2, MCs].

1914. Tanacetum corymbosum (L.) Sch.Bip. - Hort: Cseplye [8284.4, MCs].

1916. Leucanthemella serotina (L.) Tzvelev - Szegilong: Meszes [7794.3, MCs]. 
1929. Artemisia pontica L. - Atkár: Tabimajor fölött [8285.3, MCs]; Buják: Henyelpuszta felett [8183.2, MCs]; Nagyréde: a falutól D-re lévő mocsárréteken [8285.3, MCs]; Szikszó: útszélen Liget és a régi vízimalom között [7891.2, MCs].

1938. Erechtites hieracifolia (L.) Raf. ex DC. - Alacska: Cserebagos [7789.4, MCs]; Baskó: Bika-rét [7694.3, MCs]; Erdőbénye: Csorgó-völgy [7794.3, MCs]; Kemence: Nagy-Mána, erdőirtáson [8079.2, LA]; Mátraterenye-Mátraballa: a vasút mentén, Etele-puszta mellett [8085.2, MCs]; Olaszliszka: Sajgó [7794.1, 7794.3, MCs].

1941. Tephroseris integrifolia (L.) Holub - Vácrátót: Tece, homoki sztyeppréten [8381.1, LA].

1943. Senecio vulgaris L. - Bánréve: vasútállomás [7788.1, MCs].

1944. Senecio sylvaticus L. - Őrbottyán: Béke-telep, fenyőültetvényekben [8381.2, LA].

1945. Senecio viscosus L. - Őrbottyán: Béke-telep, fenyőültetvényekben [8381.2, LA].

1946. Senecio vernalis Waldst. et Kit. - Atkár-Gyöngyöshalász: az M3-as mentén [8285.3, MVA]; Biharkeresztes: a 47-es fóút mentén [8896.3, MVA]; Biharkeresztes: a település É-i szélén, vasúti átjárónál [8896.3, MVA]; Debrecen: Vámospércsi út [8496.3, MVA]; Debrecen: Egyetem tér, virágágyásban [8495.2, MVA]; Derecske-Sáránd: a 47-es fóút mentén [8695.1, 8695.2, 8595.4, MVA]; Ecséd: az M3-as mentén az ecsédi pihenőnél [8284.4, MVA]; Füzesabony-Szihalom: az M3-as mentén [8288.3, 8288.4, 8288.2, MVA]; Hajdúbagos: vasúti töltésen [8595.4, MVA]; Hajdúbagos: Hosszúpályi felé, vasúti töltésen [8596.3, MVA]; Hajdúszoboszló: Szováti útfél [8594.3, MVA]; Iklad: temető [8382.2, MVA]; Kaba: a 4-es fóút mentén, a vasútállomás közelében [8693.2, MVA]; Nagyút: az M3-as mentén [8287.3, MVA]; Nagyút-Kompolt: az M3-as mentén Nagyúttól Kálig [8287.3, MVA]; Nyírbátor: Nyírcsászári felé, vasúti átjárónál [8198.4, MVA]; Rakamaz: belterület, a vasúti átjárónál [7894.4, MVA]; Sárvár: Bajti-erdő, út mentén [8768.1, KL, MVA]; Téglás: Bököny felé, vasúti átjárónál [8296.3, MVA]; Tura: temető [8483.1, MVA]; Vát: Váti-erdő, út mentén a Kőris-patak közelében [8766.2, MVA].

1948. Senecio erucifolius L. - Nyékládháza: Köblös, az István-tó partján [8091.1, SK].

1963. Xeranthemum cylindraceum Sibth. et Sm. - Cserháthaláp: Tornyos-hegy környéke, parlagokon, bolygatott szárazgyepekben [8082.1, LA, LVD]; Eger: Nagy-Rózsás [8187.2, MCs]; Egyházasdengeleg: Hangács [8283.1, MCs]; Felsőtold: Bátor-lapos és Kozicskától ÉKre [8083.2, MCs]; Herencsény: Palócok Vigyázó Keresztje [8082.2, MCs]; Hollókő: Szár-hegy [8083.2, MCs]; Sirok: Palyag K-i részén [8087.3, MCs]; Terény: Káposztás-hegy [8082.4, MCs].

1964. Xeranthemum annuum L. - Gyöngyössolymos: Kis-hegy [8185.4, MCs]; Rózsaszentmárton: Tarcodi pincék [8184.3, MCs]; Szurdokpüspöki: Köszvény-kút felett [8184.3, MCs]; Veresegyház: bolygatott, száraz, homoki gyepekben [8381.4, LA].

1978. Carduus collinus Waldst. et Kit. - Apc-Rózsaszentmárton: Tarcod [8184.3, MCs]; Tállya: Patócs-hegy [7793.3, MCs].

1982. Cirsium boujartii (Piller et Mitterp.) Sch. Bip. - Zirc: Csengői-tető, bolygatott száraz gyepben néhány-tíz tő [8773.1, LA, LVD].

1985. Cirsium palustre (L.) Scop. - Dédestapolcsány: a Lázbérci-tározó mellett [7888.2, MCs]; Garadna: Nagy-völgy [7592.4, MCs].

1992. Silybum marianum (L.) Gaertn. - Szanda: Határok, repcevetésben [8082.4, LA, LVD].

2000. Centaurea indurata Janka - Erdőhorváti: Tér-hegy [7794.1, MCs].

2003. Centaurea cyanus L. - Apc: Miskolc [8284.1, MCs]; Besenyőtelek-Poroszló: szántókon [8389.1, MCs]; Felsőtold: Mengyi-szállás [8083.2, MCs].

2005. Centaurea triumfettii All. - Abaújszántó: Sulyom-hegy [7792.2, MCs].

2016. Hypochoeris maculata L. - Komlóska: Temető felett, Podinka [7694.4, MCs].

2017. Hypochoeris radicata L. - Csányoszró: Körcsönye-csatorna mentén, mezofil legelőn [0173.1, LA]; Hosszúhetény-Kisújbánya: Szürke-rét, savanyú talajú gyepekben [9776.3, LA].

2018. Thrincia nudicaulis (L.) Dostál - Budapest: ELTE TTK kampusz, taposott gyomnövényzetben [8580.1, LA]; Drávaszerdahely: a Drávacsepelyre vezető út melletti 
legelőn, mezofil gyepben [0174.4, LA]; Tihany: MTA BLI üdülője, taposott gyomnövényzetben [9073.3, LA, CsAI].

2026. Scorzonera purpurea L. - Kerecsend: Lógó-part [8288.1, MCs].

2027. Scorzonera hispanica L. - Szerencs: Aranka-tető [7893.1, MCs].

2037. Sonchus palustris L. - Veresegyház: Malomköz, nádasban [8381.2, LA].

2048. Taraxacum serotinum (Waldst. et Kit.) Poir. - Dány: temető [8483.3, MVA]; Tápiószentmárton: Bereg-völgy [8684.3, MCs]; Valkó: temető [8483.1, MVA]; Zsámbok: temető [8483.4, MVA].

2049. Taraxacum sect. Erythrospermum (H.Lindb.) Dahlst. - Abaújszántó-Abaújkér: Gyürtető oldala [7793.1, MCs]; Bekecs: Közép-hegy és Nagy-hegy [7893.1, MCs]; Legyesbénye: Fuló-hegy [7892.2, MCs]; Veresegyház: Ligetek, bolygatott homoki gyepekben, fenyőlultetvényekben [8381.2, LA, LVD].

2061. Crepis tectorum L. - Bánréve: vasútállomás [7788.1, MCs]; Szerencs: vasútállomás [7893.1, MCs].

2069. Hieracium echioides Lumn. - Őrbottyán: Béke-telep, bolygatott homoki gyepekben, fenyőültetvényekben [8381.2, LA].

2123. Alisma gramineum Lej. - Makó-Rákos: Vékony-ér [9789.1, NT, TA]; Prügy: Úrrét [7893.3, NT, TA]. Mindkét esetben belvizes szántón.

2125. Alisma lanceolatum With. - Karcag: az Apavári-erdőtől Ny-ra, a 4-es út mentén [8691.4, NT, TA]; Makó-Rákos: Vékony-ér [9789.1, NT, TA]. Mindkét esetben belvizes szántón.

2129. Stratiotes aloides L. - Nagyhegyes: Keleti főcsatorna [8493.4, SK].

2132. Elodea nuttallii (Planch.) H. St. John - Nagyhegyes: Keleti főcsatorna [8493.4, SK].

2138. Triglochin palustre L. - Őrbottyán: Tece-patak forrása mellett, forráslápban [8381.2, LA, LVD].

2141. Veratrum album L. - Vácrátót: Tece, lápréten, lápi füzesekben [8381.1, LA].

2144. Anthericum ramosum L. - Hort: Cseplye [8284.4, MCs].

2148. Colchicum arenarium Waldst. et Kit. - Dunaharaszti: Szent Kereszt kápolna dombja [8680.3, CsM, RZs].

2155. Ornithogalum brevistylum Wolfner - Cserhátszentiván: Szőlők [8083.1, MCs]; Parád: Ilona-völgy menti rétek [8186.1, MCs]; Pásztó: Szarka-mál [8184.1, MCs]; Szikszó: Groznik, felhagyott szőlőben [7891.1, MCs].

2157. Ornithogalum kochii Parl. - Ozora: temető, bolygatott szárazgyepekben [9276.3, LA].

2158. Ornithogalum refractum Kit. in Willd. - Veresegyház: bolygatott száraz, homoki gyepekben [8381.2, 8381.4, LA].

2159. Ornithogalum umbellatum L. - Veresegyház: gyomtársulásokban, akácosokban [8381.2, 8381.4, LA].

2167. Muscari tenuiflorum Tausch - Fót: Somlyó, löszös talajú sztyeppréten [8381.3, LA,

KA]; Tatabánya: Kő-hegy, mészköves talajú sztyeppréten [8476.1, LA].

2168. Muscari comosum (L.) Mill. - Veresegyház: Ligetek, akácosokban [8381.2, LA].

2172. Allium sphaerocephalon L. - Apc: Tarcod-hegy és Kerek-domb [8184.3, MCs]; Bér: Fekete-hegy [8182.2, MCs]; Fony: Bors-kúttól délre lévő sziklaletörésen [7593.4, MCs]; Tolcsva: Vár-hegy [7794.2, MCs].

2186. Allium angulosum L. - Baskó: Bika-rét [7694.3, MCs]; Erdőbénye: Bó-kút-völgye [7794.1, MCs]; Erdőbénye: Palánkos [7794.1, MCs]; Regéc: Nyugati-kertalja, másodlagos lápréten [7694.1, MCs]; Szegilong: Meszes [7794.3, MCs].

2187. Allium lusitanicum Lam. - Sirok: Darnó-hegy [8087.3, MCs].

2188. Allium oleraceum L. - Bodrogkeresztúr: Kakas-hegy [7894.1, MCs]; Fony: Kis-Szár-kő [7693.2, MCs]; Regéc: Dabróka-dűlő [7693.2, MCs]; Sirok: Darnó, Törökasztal felett 
[8087.3, MCs]; Sirok: Nagy-Várhegy [8087.3, MCs]; Veresegyház: Ligetek, akácosban [8381.2, LA].

2190. Allium flavum L. - Sajóvelezd: Lapos-kő [7788.2, MCs].

2191. Allium paniculatum L. s. str. - Markaz: Rókalyuk-tető [8186.1, MCs]; Sirok-KőkútTarnaszentmária: Bóna-halom 396,5 m-es csúcsa [8187.1, MCs].

2192. Convallaria majalis L. - Egerszalók: a víztározótól Ny-ra lévő erdőben [8187.2, MCs]; Egerszólát: Ádám-tető [8187.2, MCs]; Megyaszó: Hernád-magaspart, bozótosban [7792.3, MCs]; Nagytarcsa: Küdői-hegy [8481.4, MCs].

2193. Maianthemum bifolium (L.) F.W.Schmidt - Mátramindszent: Boldogasszony magasa és a Balcsó-emlékmű közötti völgy [8085.2, MCs]; Szendrő: Billér-hegy [7690.1, MCs].

2195. Polygonatum latifolium (Jacq.) Desf. - Gyöngyöspata-Gyöngyöstarján: Gereg-hegy [8184.4, MCs]; Veresegyház: Ivacs, akácosokban [8381.4, LA].

2197. Polygonatum multiflorum (L.) All. - Szendrő: Billér-hegy [7690.1, MCs].

2219. Najas marina L. - Egerszalók: a víztározóban [8187.2, MCs]; Nagyhegyes: Keleti főcsatorna [8493.4, SK].

2220. Najas minor All. - Karcag: Magyarka, rizsföldön [8791.3, NT, TA]; Nagyhegyes: Keleti föcsatorna [8493.4, SK].

2222. Gagea pratensis (Pers.) Dumort. - Albertirsa: Lipina- és Hársas-erdő [8783.2, MCs].

2225. Gagea pusilla (Schmidt) Schult. et Schult f. - Abaújszántó: Sulyom-hegy [7792.2, MCs]; Golop: Golopi-erdő széle [7793.3, MCs].

2227. Gagea villosa (M. Bieb.) Duby - Veresegyház: Ligetek, akácosokban [8381.2, LA].

2235. Lilium martagon L. - Aldebrő: Cser [8287.1, MCs]; Egerszólát: Ádám-tető [8187.2, MCs]; Monok: Nyírjes és Falu gaza-hegy között [7892.2, MCs].

2237. Yucca filamentosa L. - Veresegyház: Ligetek, bolygatott, spontán cserjésedő gyepekben [8381.2, LA].

2238. Sternbergia colchicifolia Waldst. et Kit. - Pázmánd: Zsidó-hegy [8777.2, CsM].

2252. Iris graminea L. - Aszaló: Erdők széle, kontinentális erdősszytepp-erdő aljnövényzetében [7791.4, MCs]; Botykapeterd: a falutól keletre, üde-félszáraz gyepben [9973.1, LA]; Fony: Fonyi-rétek [7593.4, MCs]; Fony: Szár-kő-oldal [7594.3, MCs]; Pásztó: Szarka-mál, felhagyott szőlőben [8184.1, MCs].

2254. Iris sibirica L. - Regéc: Nyugati-kertalja [7694.1, MCs].

2256. Iris pumila L. - Tállya: Dorgó-tető oldala [7793.4, MCs]; TiszaszentimreÚjszentgyörgy: temető [8590.3, MVA].

2261. Crocus reticulatus Steven - Albertirsa: Lipina- és Hársas-erdő [8783.2, MCs].

2284. Juncus articulatus L. - Veresegyház: Malomköz, belvizes szántón [8381.2, LA].

2288. Luzula pallidula Kirschner - Mikóháza: Köblös és Szompoly [7595.2, MCs].

2296. Festuca gigantea (L.) Vill. - Sirok: Kígyós lápja [8087.3, MCs].

2301. Festuca rubra L. - Kerecsend: Lógó-part [8288.1, MCs]; Pánd: Hársas-völgy [8683.4, MCs].

2306. Festuca pseudovaginata Penksza - Őrbottyán: Liget lovarda mellett, bolygatott nyílt homokpusztagyepen [8381.2, LA].

2314. Festuca pseudodalmatica Krajina ex Domin - Gyöngyössolymos: Kis-hegy, Csák-kő [8185.4, MCs].

2315. Festuca valesiaca Schleich. ex Gaudin - Pánd: Hársas-völgy [8683.4, MCs].

2318. Lolium multiflorum Lam. - Prügy: Úrrét [7893.3, NT, TA]; Szentes: a település É-i szélén, hulladéklerakó rekultivációja során kialakított depónián [9387.1, NT, TA].

2322. Vulpia myuros (L.) C.C.Gmel. - Ecséd: az M3-as Ecsédi pihenőhelye mellett [8284.4, MCs]; Erdőbénye: Petrás-tető déli bokorerdeje [7794.3, MCs]; Gyöngyöstarján: Hosszúhegy [8185.3, MCs]; Hatvan: vasútállomás, sínek között [8384.1, MCs]; Szentes: a település É-i szélén, hulladéklerakó rekultivációja során kialakított depónián [9387.1, NT, TA]; 
Tállya: Vány-hegy, szőlők között [7793.4, MCs]; Tarcal: Murat-völgy, szőlőültetvény szélén [7894.3, NT, TA]; Veresegyház: pionír homoki gyepekben, útszéleken [8381.2, LA].

2324. Poa bulbosa L. - Veresegyház: homoki gyepekben [8381.2, 8381.4, LA].

2332. Poa scabra Kit. - Abaújszántó: Sátor-hegy, déli oldal [7793.1, MCs]; ArkaBoldogkőváralja: Tó-hegy [7693.1, MCs]; Erdőbénye: Petrás-tető déli bokorerdeje [7794.3, MCs]; Tállya: Patócs-hegy [7793.3, MCs]; Tállya: Dorgó-tető és Vár-hegy, felhagyott szőlőben [7793.4, MCs].

2333. Poa nemoralis L. - Gyöngyöstarján: Fajzati út melletti ültetett tölgyesben [8185.3, MCs].

2334. Poa palustris L. - Vácrátót: Sződrákosi-patak mentén, nedves gyepben [8281.3, LA].

2345. Cynosurus cristatus L. - Bokor: Bokori-ág mentén, Szőlők alatt, fás legelőn [8083.3, MCs].

2347. Apera spica-venti (L.) P.Beauv. - Gömörszőlős: Egerdő-tető [7688.2, MCs].

2356. Melica transsilvanica Schur - Hort: Cseplye [8284.4, MCs]; Szikszó: sajóvámosi és sajópálfalai határút mezsgyéje [7891.1, MCs]; Veresegyház: bolygatott homoki gyepekben [8381.2, 8381.4, LA].

2357. Melica altissima L. - Bénye: közvetlenül a falutól D-re [8683.3, MCs]; Bér: Filagóriahegy és Nagy-Mulató-hegy [8182.2, MCs]; Buják: Vár-hegy [8183.1, MCs]; Erdőbénye: Ördög-kő-sor [7794.1, MCs]; Gyöngyöspata: Havas [8184.4, MCs]; Megyaszó: Hernádmagaspart, bozótosban [7792.3, MCs]; Olaszliszka: Meszesmajor [7794.3, MCs]; Pere: Legelö-dűlő [7792.2, MCs].

2375. Bromus arvensis L. - Buják: az ecsegi út mellett, parlagon [8183.1, LA].

2376. Bromus japonicus Thunb. - Vértesszőlős: a Kovács-hegy lábainál, löszgyepben [8376.3, LA].

2380. Bromus erectus Huds. - Felsődobsza: Hernád-magaspart [7792.1, 7792.2, MCs].

2381-2382. Bromus pannonicus agg. - Tatabánya: Kő-hegy, mészkősziklagyepben [8476.1, LA].

2390-2391. Brachypodium pinnatum agg. - Hort: Cseplye [8284.4, MCs].

2393. Elymus caninus (L.) L. - Erdőbénye: Peres [7794.1, MCs]; Gyöngyöspata: Havas [8184.4, MCs]; Monok: Henc [7893.1, MCs]; Monok: Falu gaza-hegy [7892.2, MCs].

2394. Elymus elongatus (Host) Runemark - Budapest: Budapest, az M0 autóút mentén elszórtan az M5-östől az M31-ig [8481.4, 8581.2, 8581.4, 8681.1, 8681.2, NT, TA]; Veresegyház: Medveotthon mellett, gyomos mezsgyén [8381.4, LA].

2398. Aegilops cylindrica Host - Atkár: gyöngyösi út menti parlagon [8285.3, MCs]; Pánd: a Hársas-völgy bejárati útja mellett [8683.4, MCs].

2404. Secale sylvestre Host - Veresegyház: Ligetek, bolygatott homoki gyepben [8381.2, LA].

2405. Hordeum jubatum L. - Apaj: Szúnyogpuszta, szikes legelőn [8880.2, LA].

2412. Hordelymus europaeus (L.) Less. ex Harz - Megyaszó: Hernád-magaspart, bozótosban [7792.3, 7892.1, MCs].

2420. Helictotrichon pubescens (Huds.) Pilg. - Veresegyház: Gyermekliget Óvoda, az óvoda kaszált gyepében [8381.2, LA].

2421. Helictotrichon compressum (Heuff.) Henrard - Magyarnándor: Kő-oldal, löszös talajú sztyeppréten [8082.1, LA].

2426. Ventenata dubia (Leers) Coss. - Abaliget: 295m magas domb, a falutól nyugatra, erodált talajú gyepekben [9874.4, LA]; Gyöngyös: Sár-hegy, parlagon [8285.2, MCs]; Hosszúhetény-Kisújbánya: Szürke-rét, mezofil gyepek erodált talajú foltjaiban [9776.3, LA].

2427. Koeleria glauca (Spreng.) DC. - Őrbottyán: Liget lovarda mellett, bolygatott nyílt homokpusztagyepen [8381.2, LA]; Veresegyház: homokbánya, bolygatott homoki gyepben [8381.4, LA].

2434. Trisetum flavescens (L.) P. Beauv. - Salgótarján-Somoső: Belső-cseres, mezofil réten [7885.1, LA].

2435. Deschampsia caespitosa (L.) Beauv. - Csécse: Cseralja bánya [8183.2, MCs]. 
2440. Hierochloë repens (Host) P. Beauv. - Tata: a Réti-halastavak északi szomszédságában, gyepparcellák közötti mezsgyén [8375.2, LA]; Veresegyház: bolygatott gyepekben, erdőszéleken [8381.2, 8381.4, LA].

2441. Anthoxanthum odoratum L. - Apc: Kopasz-hegy [8284.1, MCs].

2443. Holcus lanatus L. - Recsk: Szederjes-állás [8186.2, MCs]; Veresegyház: Malomköz, nedves gyomnövényzetben [8381.2, LA].

2449. Agrostis canina L. - Vác: Gyadai-rétek, mezofil réten [8180.4, LA].

2452. Calamagrostis arundinacea (L.) Roth. - Tállya: Patócs-hegy [7793.3, MCs].

2459. Phleum paniculatum Huds. - Abaliget: vasútállomás, útszéli gyomnövényzetben [9874.1, LA]; Magyaregregy: Máré utca, útszéli gyomnövényzetben [9775.4, LA].

2464. Alopecurus myosuroides Huds. - Gárdony-Dinnyés: vasútállomás, útszéli gyomnövényzetben [8877.1, LA]; Karcag: az Apavári-erdőtől Ny-ra, a 4-es út mentén, belvizes szántón [8691.4, NT, TA]; Szarvas: a Szentesi út mentén, árokban [9189.3, NT, TA]; Szentes: a település É-i szélén, hulladéklerakó rekultivációja során kialakított depónián [9387.1, NT, TA].

2471. Milium effusum L. - Erdőbénye: Király-kert [7794.1, MCs]; Fony: Fehér-kút, bükkösben [7593.4, MCs]; Megyaszó: Hernád-magaspart, bozótosban [7892.1, MCs].

2473. Stipa capillata L. - Bekecs: Közép-hegy és Nagy-hegy [7893.1, MCs]; Bercel: Galga menti dombok [8182.1, MCs]; Herencsény: Madarász-bérc Ny-i lába [8083.1, MCs]; Hort: Cseplye [8284.4, MCs]; Nógrádsáp: Répás [8182.1, MCs]; Pécel: Száraz-hegy [8582.1, MCs].

2475. Stipa tirsa Steven em. Čelak. - Gyöngyöspata: Tamás-domb [8184.2, MCs]; Hort: Cseplye [8284.4, MCs]; Nagytarcsa: Küdői-hegy [8481.4, MCs]; Tápióság: Pándi-hegy [8683.2, MCs].

2476. Stipa dasyphylla (Czern. ex Lindem.) Trautv. - Boldogkőúffalu: Falu-hegy és Feketehegy [7693.4, MCs]; Gyöngyöstarján: Mulató [8185.3, MCs].

2478. Stipa borysthenica Klokov ex Prokudin - Ôrbottyán: Liget lovarda mellett, bolygatott nyílt homokpusztagyepen [8381.2, LA].

2479. Stipa pulcherrima K.Koch - Tápióbicske: Agyagásó [8684.1, MCs]; Tolcsva: Vár-hegy [7794.2, MCs].

2482. Danthonia alpina Vest - Bokor: Bokori-ág mentén, Szőlők alatt, fás legelőn [8083.3, MCs]; Erdőbénye: Meszes és Sötétes-tető közötti gyep, Meszes-tisztás [7794.3, MCs]; Erdőbénye: Mulató 2005 [7794.1, MCs]; Erdőhorváti: Kavicsos-rét [7794.1, MCs]; Olaszliszka: Kondás-kút mellett [7794.1, MCs]; Sirok: Törökasztal melletti tisztáson [8087.3, MCs].

2483. Danthonia decumbens (L.) DC. - Bodony: Lágyasi-legelő és a környező gyepek [8085.2, MCs]; Boldogkőváralja-Hernádcéce: Aba-hegy [7693.3, MCs]; Csányoszró: Köcsönye-csatorna menti rétek, mezofil réten [0173.1, LA]; Gyöngyöspata: Havas ÉNy-i lábánál lévő rét [8184.4, MCs].

2486. Nardus stricta L. - Ispánk: az Ispánki-patak völgyében, sovány gyepekben, mezofil és lápréteken [9164.2, LA]; Kisrákos: Fodorszer, sovány gyepben [9164.2, LA]; Kisrákos: a falu keleti szélén, mezofil gyepekben [9164.4, LA].

2487. Cleistogenes serotina (L.) Keng - Sajóvelezd: Lapos-kő [7788.2, MCs].

2488. Eragrostis minor Host - Abaújszántó: vasútállomás [7793.1, MCs]; Berente: a vasút mentén [7789.4, MCs]; Berente-Sajószentpéter: a vasút mentén, különösen a vasúti megállóhelyeken [7790.3, MCs]; Miskolc-Szirmabesenyő: a vasút mentén, különösen a vasúti megállóhelyeken [7890.2, 7890.4, MCs]; Sajóecseg-Sajókeresztúr: a vasút mentén, különösen a vasúti megállóhelyeken [7890.2, 7890.4, MCs]; Szegilong: Erdőbénye vasúti megállóhely [7795.3, MCs]; Veresegyház: száraz gyomnövényzetben [8381.2, 8381.4, LA].

2489. Eragrostis cilianensis (All.) Vignolo ex Janch. - Tófalu: tökföldön, homokon [8287.1, MCs]. 2490. Eragrostis pilosa (L.) P.Beauv. - Miskolc: Tiszai pályaudvar [7990.2, MCs]; Ózd: buszpályaudvar [7787.4, MCs]; Putnok: vasútállomás [7788.2, MCs]; Szendrő-Szuhogy: a két települést összekötő műút mentén [7690.1, MCs]; Szerencs: vasútállomás [7893.1, MCs]. 
2497. Eleusine indica (L.) Gaertn. - Mórahalom: strandfürdő [9785.3, SK].

2503. Panicum dichotomiflorum Michx. - Naszály: a Fényes-patak mellett, tarlón; a 2006-os megtalálása óta nem került elő [8375.2, LA].

2504. Panicum capillare L. s. str. - Nógrádkövesd: vasútállomás [8182.1, MCs]; Putnok:

Fodor tüzép telephelye [7788.2, MCs]; Veresegyház: Ligetek, útszéleken [8381.2, LA].

2506. Panicum ruderale (Kitag.) Lyssov - Bánréve: határátkelő mellett [7688.3, MCs]; Szendrő: Kis-hegy, szántókon, parlagokon [7690.1, MCs]; Szendrő-Szuhogy: a két települést összekötő műút mentén [7690.1, MCs].

2514. Setaria verticillata (L.) P. Beauv. - Veresegyház: Budapesti út, útszéli gyomnövényzetben [8381.2, LA].

2516. Setaria verticilliformis Dumort. - Budapest: Szerémi sor, útszéli gyomnövényzetben [8580.1, LA].

2517. Cenchrus incertus M.A. Curtis - Veresegyház: Ligetek, útszéli gyomnövényzetben [8381.2, LA]; Veresegyház: Patak utca, útszéli gyomnövényzetben [8381.4, LA].

2521. Chrysopogon gryllus (L.) Trin. - Kisnána: Macskavár [8186.2, MCs].

2522. Bothriochloa ischaemum (L.) Keng - Veresegyház: az őrbottyáni út mellett, bolygatott szárazgyepben [8381.2, LA].

2530. Lemna trisulca L. - Gömörszőlős: Mocsolyák [7688.2, MCs].

2549. Schoenoplectus supinus (L.) Palla - Karcag: az Apavári-erdőtől Ny-ra, a 4-es út mentén, belvizes szántón [8691.4, NT, TA].

2552. Schoenoplectus mucronatus (L.) Palla - Karcag: az Apavári-erdőtől Ny-ra, a 4-es út mentén, belvizes szántón [8691.4, NT, TA].

2556-2559. Bolboschoenus maritimus agg. - Veresegyház: Álomvölgyi-víztározó, vízpartokon állományalkotó [8381.4, LA].

2572. Eleocharis uniglumis (Link) Schult. - Mogyoród: Álomhegyi-tó, forráslápban [8381.4, LA]; Őrbottyán: Tece-patak forrása mellett, forráslápban [8381.2, LA].

2578. Cyperus flavescens L. - Veresegyház: Ivacsi-tó, taposott, nedves gyomnövényzetben a tóparton [8381.4, LA].

2579. Cyperus fuscus L. - Veresegyház: Malomköz, belvizes szántón [8381.2, LA].

2580. Cyperus difformis L. - Karcag: az Apavári-erdőtől Ny-ra, a 4-es út mentén, belvizes szántón [8691.4, NT, TA].

2606. Carex disticha Huds. - Tata: Réti-malom, mocsárréteken [8375.2, LA].

2609. Carex divisa Huds. - Veresegyház: Piactér, vízállásos mélyedésben [8381.2, LA].

2610. Carex elata All. - Szendrő: Vásártértől D-re lévő egykori Bódva meder mentén [7690.1, MCs]; Veresegyház: Sződrákosi-patak mentén, magassásosokban állományalkotó [8381.2, LA].

2611. Carex acuta L. - Monok: Hosszú-völgy és Oláh-völgy [7792.4, MCs].

2615. Carex hartmanii Cajander - Háromhuta: Mlaka-rét, lápréten [7594.3, LA].

2621. Carex flacca Schreb. - Őrbottyán: Tece-patak forrása mellett, kiszáradó láprét [8381.2, LA].

2622. Carex humilis Leyss. - Korlát: Kővágó [7693.2, MCs].

2623. Carex digitata L. - Monok: Szőlős-hegy [7792.4, MCs]; Sárospatak: Király-hegy [7695.3, MCs].

2626. Carex tomentosa L. - Hort: Cseplye [8284.4, MCs].

2628. Carex montana L. - Feldebrő: Cser [8187.3, MCs].

2631. Carex pendula Huds. - Fony: Cigány-tövis melletti patak partján [7693.2, MCs].

2633. Carex pseudocyperus L. - Komlóska: a Zsidó-rét lápján [7694.2, NT, TA].

2635. Carex pilosa Scop. - Szada: Margita [8381.4, MCs].

2636. Carex pallescens L. - Monok: Falu gaza-hegy alja [7892.2, MCs]. 
2640. Carex rostrata L. - Fony: Nagy-Dinnyés-tó, néhány tő a kiszáradt tó peremén [7693.2, MCs]; Fony: Szár-kő-rét és Fonyi-rétek, szórványosan, kisebb foltokban a vízszivárgásos helyeken [7593.4, 7594.3, MCs].

2641. Carex vesicaria L. - Fony: Nagy-Dinnyés-tó és Kis-Dinnyés-tó [7693.2, MCs]; Fony: Szár-kő-rét és Fonyi-rétek [7593.4, 7594.3, MCs]; Pilisszentlászló: Hosszú-rét, erdei mocsárban [8280.3, LA].

2644. Carex liparicarpos Gaudin - Veresegyház: Ligetek, homoki gyepekben [8381.2, LA].

2647. Carex michelii Host - Feldebrő: Cser [8187.3, MCs]; Fony: Gergely-hegy, bokorerdőben [7593.4, MCs]; Legyesbénye: Fuló-hegy [7892.2, MCs]; Monok: Hosszú-völgy és Oláh-völgy [7792.4, MCs]; Sárospatak: Felső-Mancsalka-hegy [7695.3, MCs]; SzerencsOnd: Kassa-hegy [7893.1, MCs].

2650. Carex secalina Wahlenb. - Besenyőtelek: Zsidó-Csincsa, ugaron [8288.4, MCs]; Pétfürdő: Koldus-telek [8874.2, MA, MVA].

2652. Carex lepidocarpa Tausch - Örbottyán: Tece-patak forrása mellett, forráslápban [8381.2, LA].

2655. Carex hostiana DC. - Mogyoród: Álomhegyi-tó, lápréten [8381.4, LA]; Őrbottyán: Tece-patak forrása mellett, forráslápban [8381.2, LA]; Vácrátót: a falu déli határában, nedves réten [8281.3, LA].

2656. Carex distans L. - Monok: Hosszú-völgy és Oláh-völgy [7792.4, MCs].

2657. Cypripedium calceolus L. - Gömörszőlős: Bikás-tető [7688.2, MCs].

2658. Epipactis palustris (L.) Crantz - Solymár: agyagbánya a Mátyás-dombtól K-re [8479.2, CsM].

2659. Epipactis microphylla (Ehrh.) Sw. - Gödöllő: Kis-disznó-szállás [8382.3, TGy]; Gödöllő: Csurgó [8482.1, TGy].

2660.1. Epipactis leptochila (Godfery) Godfery - Diósjenő: a Závoz felé menő aszfaltozott út alatt, a lejtőn [8080.1, CsM, RZs].

2660.2. Epipactis neglecta (Kümpel) Kümpel - Bozsok: Írottkőalja [8664.2, MS].

2661. Epipactis voethii Robatsch - Bozsok: Írottkőalja [8664.2, MS].

2662. Epipactis pontica Taubenheim - Háromhuta: Kis-közép-bérc [7694.2, TGy].

2669. Epipactis albensis Nováková et Rydlo - Vác: az Égető-szigettől D-re, a kerékpárút mellett [8280.4, CsM, MS].

2671. Epipactis muelleri Godfery - Buják: Csirke-hegy, xerotherm cserjés szegélyében [8183.1, LA, LVD].

2673. Epipactis helleborine (L.) Crantz - Budapest III.: Hármashatár-hegy, a Nagy-Farkastorok mellett [8480.1, CsM]; Csobánka: pilisszentkereszti Szurdok D-i végénél lévő kőbánya [8379.2, CsM]; Csobánka: Ziribár-nyereg [8379.2, CsM]; Esztergom: Cserepes-völgy [8278.4, CsM]; Pilisszentlászló: Szeles-hegy lába (Bükkös-patak völgye), útszegélyben [8279.4, CsM]; Szada: Margita [8381.4, TGy].

---. Epipactis moravica Batoušek - Csehimindszent: Kutyori-patak [8967.4, TGy].

2675. Cephalanthera rubra (L.) Rich. - Szada: Margita [8382.3, TGy].

2676. Cephalanthera damasonium (Mill.) Druce - Csobánka: pilisszentkereszti Szurdok D-i végénél lévő kőbánya [8379.2, CsM]; Csobánka: Ziribár-nyereg [8379.2, CsM]; Dunabogdány: Púp-hegy [8280.1, CsM]; Esztergom: Sátorkőpusztai homokbánya [8278.4, CsM]; Esztergom: Cserepes-völgy [8278.4, CsM]; Pilismarót: Basaharci völgy [8179.3, CsM]; Pomáz: Kő-hegy lába [8380.1, CsM].

2677. Cephalanthera longifolia (L.) Fritsch - Budapest II.: Szépvölgyi-dűlő [8479.4, CsM]; Budapest XVII.: a Merzse-mocsár melletti tölgyesben [8581.4, CsM]; Csobánka: Kerekeshegy [8379.4, CsM]; Dunabogdány: a Sós-hegy és a Púp-hegy között [8280.1, CsM]; Kecskemét: az 54-es út mellett, a Rigó vendéglőtől DNy-ra lévő nyarasban [9183.4, CsM, RZs]; Solymár: Kerek-hegy [8479.2, CsM]; Tahitótfalu: 316 m-es hegy a Nádas-tói-réttől Kre [8280.1, CsM]. 
2680. Neottia nidus-avis (L.) Rich - Budakalász: Ezüst-hegy [8380.3, CsM]; Budapest III.: Hármashatár-hegy, Guckler-szikla fölött és a Nagy-Farkas-torok mellett [8480.1, CsM]; Dunabogdány: Púp-hegy [8280.1, CsM]; Pilismarót: Basaharci-völgy [8179.3, CsM]; Szendrő: Billér-hegy [7690.1, MCs]; Tahitótfalu: 316 m-es hegy a Nádas-tói-réttől K-re [8280.1, CsM].

2686. Platanthera bifolia (L.) Rich. - Perbál: a 411 m-es csúcstól Ny-ra [8478.2, CsM].

2691. Dactylorhiza sambucina (L.) Soó - Pilisborosjenő: Köves-bérc [8379.4, CsM].

2700. Anacamptis morio (L.) Bateman et al. - Hernádcéce: Aba-hegy [7693.3, MCs]; Szigetmonostor: Hegyre való [8380.4, CsM]; Újtikos: Szigetvári-legelő [8093.3, TGy].

2704. Orchis purpurea Huds. - Biatorbágy: Nyakas-kőtől ÉNy-ra [8578.2, CsM]; Dömös: 382-es csúcs, a Lukács-ároktól É-ra [8279.3, CsM]; Dunabogdány: Körös-hegy [8280.1, CsM]; Esztergom: Kis-Strázsa-hegy [8278.1, CsM]; Sopron: Fehér út [8366.1, TGy].

2707. Orchis mascula subsp. signifera (Vest) Soó - Pilismarót: Sas-hegy [8178.4, CsM].

2709. Anacamptis palustris (Jacq.) Bateman et al. - Kunszentmiklós: az Apaj-csatornától Dre, a müút mellett [8980.4, CsM, TGy].

2711. Himantoglossum jankae Somlyay et al. - Visegrád: Fekete-hegy [8279.2, CsM].

2712. Anacamptis pyramidalis (L.) Rich. - Kunszentmiklós: az Apaj-csatornától D-re, a műút mellett [8980.4, CsM, TGy].

2714. Ophrys apifera Huds. - Gánt: Bányatelep, a Bányászati Múzeummal szemközti dombon [8676.1, LÁ].

\section{Köszönetnyilvánítás}

Köszönetünket fejezzük ki Lantos Árpádnak és Makádi Sándornak publikálatlan adataik közlésének lehetőségéért, valamint Bartha Zsoltnak, Csathó András Istvánnak, Füleki Gábornak, Juhász Melindának, Kelemen Andrásnak, Kovács Anikónak, Kulcsár Lászlónak, Lovas-Kiss Ádámnak, Lukács Balázs Andásnak, Mészáros Andrásnak, Pelles Gábornak, Raksányi Zsoltnak, Türke Ildikó Juditnak közremúködésükért a terepmunkában. Molnár Csaba köszöni Hudák Katalinnak és Gyulai Ivánnak, hogy felhívták figyelmét a Cypripedium calceolus új lelőhelyére. Hálásak vagyunk Bartha Dénesnek, Schmidt Dávidnak és Tiborcz Viktornak a kézirat lektorálásáért és hasznos észrevételeikért. A kutatás a TÁMOP-4.2.4.A/211/1-2012-0001 és TÁMOP-4.2.2.B-15/1/KONV-2015-0001 programok keretében, az OTKA K108992 pályázat támogatásával valósult meg.

\section{Irodalom}

Bartha D., Király G., Schmidt D., Tiborcz V., Barina Z., Csiky J., Jakab G., Lesku B., Schmotzer A., Vidéki R., Vojtкó A. \& Zólyomi Sz. (szerk.) (2015): Magyarország edényes növényfajainak elterjedési atlasza. Nyugat-magyarországi Egyetem Kiadó, Sopron, 329 pp.

KIRÁly G. (szerk.): Új Magyar Füvészkönyv. Magyarország hajtásos növényei. Határozókulcsok. Aggteleki Nemzeti Park Igazgatósága, Jósvafo".

NikLFELD H. (1971): Bericht über die Kartierung der Flora Mitteleuropas. - Taxon 20 (4): 545-571.

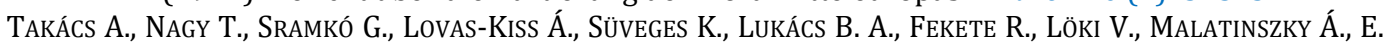
Vojtkó A., Koscsó J., Pfliegler W. P., Nótári K. \& Molnár V. A. (2016): Pótlások a Magyarország edényes növényfajainak elterjedési atlaszához I. - Kitaibelia 21 (1): 101-115.

Beérkezett / received: 2016. 11. 07. • Elfogadva / accepted: 2016. 11. 18. 